'FIRE BURN AND CAULDRON BUBBLE': IRON AGE AND EARLY ROMAN CAULDRONS OF BRITAIN AND IRELAND

$$
\text { Jody Joy }
$$

Museum of Archaeology and Anthropology, Downing Street, Cambridge CB2 3DZ, jpj32@cam.ac.uk

"A man can live to 50 but a cauldron will live to 100" - Old Kazakh saying

This paper presents a re-examination of Iron Age and early Roman cauldrons, a little studied but important artefact class that have not been considered as a group since the unpublished study of Loughran (1989). Cauldrons are categorised into two broad types (projecting-bellied and globular) and four groups. New dating evidence is presented, pushing the dating of these cauldrons back to the fourth century BC. A long held belief that cauldrons are largely absent from Britain and Ireland between 600 and 200 BC is also challenged through this re-dating and the identification of cauldrons dating from 600-400 BC. Detailed examination of the technology of manufacture and physical evidence of use and repair indicates that cauldrons are technically accomplished objects requiring great skill to make. Many have been extensively repaired, showing they were in use for some time. It is argued that owing to their large capacity cauldrons were not used every day but were instead used at large social gatherings, specifically at feasts. The social role of feasting is explored and it is argued that cauldrons derive much of their significance from their use at feasts, making them socially powerful objects, likely to be selected for special deposition.

\title{
INTRODUCTION
}

Cauldrons are an emblematic class of object. They are found across much of northwest Europe (Bochnak 2011, Fig. 3) and appear in some of the most well-known deposits of the period for example at La Tène and Hochdorf (Vouga 1923; Biel 1987). They also feature heavily in the Irish and Welsh early medieval literature, which has so often been drawn upon in Iron Age studies (e.g. Green 1998). Yet cauldrons remain enigmatic and little is known for certain about their usage and social significance.

A number of catalogues of cauldrons from Britain and Ireland have been produced (see below). These identify two broad groups of prehistoric cauldron based on their technology and their date of manufacture: 
1. Late Bronze Age/Early Iron Age or 'Atlantic' (hereafter 'Atlantic') - these consist of multiple pieces of copper-alloy riveted together. They are constructed in layers, each riveted inside the other. These cauldrons have outward projecting rims, referred to here as 'brims', and the ring handles are most often attached to the brim.

2. Iron Age/Early Roman (hereafter 'IA/ER') - these cauldrons are most commonly made of copper-alloy with iron components and are non-brimmed. Large copper-alloy bowls are formed from a single sheet. Upper bands of iron and/or copper-alloy are riveted to the bowl. The band fits on the outside of the bowl. Where two or more bands exist, the central band sits inside the bowl and the upperband. Where rims and handles survive they are made of iron. Handles are attached to the vertical wall of the bowl/band rather than the rim. Various forms or groupings of cauldrons of this date are evident, as discussed later in this paper.

There is a long history of research of Atlantic cauldrons (e.g. Leeds 1930; Hawkes \& Smith1957; Gerloff 1986; Briggs 1987) culminating in Gerloff's (2010) comprehensive catalogue. British and Irish IA/ER cauldrons have remained relatively poorly understood with most recent discussions confined to chapters within regional catalogues of Iron Age material culture (Fox 1946; Hawkes 1951; Piggott 1952-3; Raftery 1980; 1983; Spratling 1972; Macgregor 1976; Macdonald 2007; Gerloff 2010). The aims of this paper are to re-examine IA/ER cauldrons from Britain and Ireland, concentrating on typology, chronology and the social significance of cauldrons for Iron Age society.

IA/ER cauldrons are defined by their difference of manufacture and technology from the copper-alloy Atlantic cauldrons. Although cauldrons of similar form are used well into the Roman period (Hawkes 1951, 180-181), different manufacturing techniques such as casting were employed. The later Roman examples are also generally made of one-piece. A full catalogue of IA/ER cauldrons is presented as Appendix B. This has been compiled from information derived during museum visits by the author as well as that provided in various catalogues, in particular Loughran (1989), but also Spratling (1972), Macgregor (1976), Raftery (1980; 1983), Macdonald (2007) and Gerloff (2010). 
In total, the catalogue of IA/EA cauldrons (Appendix B) comprises at least 67 cauldrons from 40 separate contexts. Five cauldrons dating to $600-400$ BC (Appendix A) and a further five cauldrons which are possibly IA/ER, or have surviving elements that could have originated from IA/ER cauldrons (Appendix C), are also listed, making a total number of 77 cauldrons. Many discoveries were made in the $18^{\text {th }}$ and $19^{\text {th }}$ centuries from bogs or other watery places; consequently the available contextual information is often quite limited. Fortunately, recent discoveries mean that more data is now available for analysis. Information from a site discovered in 2004 near the village of Chiseldon, North Wiltshire, is particularly important and will be drawn upon heavily in this paper. The Chiseldon find comprises 17 complete cauldrons and fragments from many others deposited in one episode in a large pit, $2 \mathrm{~m}$ in diameter, especially dug for the purpose (Joy \& Baldwin forthcoming). This is the most number of complete cauldrons from a single context known from Iron Age Europe. The site was excavated in 2005 by Wessex Archaeology and conservators from the British Museum. The cauldrons were block-lifted and have been carefully excavated at the conservation laboratories of the British Museum. The high level of available contextual information means that the Chiseldon cauldrons represent an unparalleled opportunity to inform vessel form, function, the technology of manufacture and social significance.

\section{MORPHOLOGY AND TERMINOLOGY}

The terminology used throughout this paper, but particularly the appendices, is described in Fig. 1. This terminology broadly follows the conventions set out by Gerloff (2010, Fig. 2). IA/ER cauldrons have been previously catalogued and discussed by Fox (1946, 42-44), Hawkes (1951), Piggott (1952-3), Macgregor (1976), Raftery (1980; 1983), Loughran (1989), Macdonald (2007, 88-97) and Gerloff (2010, Appendix 3). There is general consensus that they can be categorised into two broad groups: 'Globular'/'Battersea' and 'Projectingbellied'/'Santon' (Hawkes 1951, 179; Piggott 1952-3, 13; Macgregor 1976, 150-152; Raftery 1980, 57). The first has a globular or hemispherical-shaped body. The second has a wide cylindrical neck above a body with distinctive shoulder carination, hence the name projecting-bellied (Fig. 2).

Further sub-division has been suggested, particularly of the globular group. For example, Fox $(1946,43)$ splits globular cauldrons into two groups based on whether the body is made of two pieces (bowl and band) or a single sheet. Hawkes $(1951,182)$ and Raftery $(1980,57)$ also note differences in size, form and the use of 
materials within the globular group. Spratling $(1972,235-238)$ goes further, dividing globular cauldrons into three groups (Spratling's Groups II-IV). Like Fox, Spratling draws a distinction between cauldrons made of two or more pieces (Group II) and from a single sheet (Group III \& IV). Groups III and IV are defined by the attachment of the handles to the body (III) or the rim (IV) of the vessel. In contrast, Loughran $(1989,7)$ stresses the fact that most typologies encompass cauldrons with globular-shaped bowls and cauldrons with hemispherical bowls and straight or slightly in-turned sides within the globular group. Accordingly, she creates a third type: cauldrons with hemispherical bowls and straight/slightly in-turned sides. Her globular group is also sub-divided into one-piece and composite globular vessels 'made of two or more parts'.

Macdonald (2007, 88-97) and Gerloff (2010, Appendix 3) are the most recent discussions. They take very different approaches. Macdonald (2007, 92-97) follows Spratling's groups with slight refinements. Gerloff (2010, Fig. 9.1) divides the cauldrons into no fewer than eight separate groups. Projecting-bellied cauldrons are split between British ('Type Santon') and Irish examples ('Type Ballymoney'), based on their profiles and the arrangement of the upper band. Globular cauldrons are sub-divided into six groups, three more than Spratling and Macdonald. Gerloff $(2010,375)$ splits Spratling's Group II into 'Walthamstow/La Tène' and 'Spetisbury/Baldock' variants. This is done to distinguish between cauldrons of two bands whose upper band, handles, and rim is of iron ('Type Walthamstow/ La Tène') and those with two copper-alloy bands but with iron rims and handles ('Type Spetisbury/Baldock'). Gerloff $(2010,378)$ places Kyleakin into its own group based on the distinctive profile of the vessel. The Drumlane cauldron is also assigned to its own group.

Of the main classifications of cauldrons, although Gerloff's typology is useful, as it incorporates the considerable typological variation present, because of the relatively small number of cauldrons known to date, her classification is probably too complicated. Loughran's general categorisation based on vessel profile has the merit of being simple and it relates to the whole vessel, but owing to the fragmentary nature of some of the cauldrons, it is difficult to differentiate between globular and straight-sided. It is also uncertain how important this difference was. For example a recent European typology places globular and straight-sided cauldrons side-by-side (Bataille 2008, Fig.18). 
Taking all of these factors into account, it is argued that Spratling's typology with Macdonald's (2007, 92-97) amendments most closely fit the current corpus. This can be summarised as follows (Fig. 3):

- Group I-Projecting-bellied

Also known as the 'Santon' form. Comprise a copper-alloy bowl of one-piece with a projecting belly and distinctive shoulder carination. This is attached by rivets to an upper band formed from one or two pieces of copper-alloy sheet. Handles and rim are of iron and are attached to the upper band.

- Group II-Globular composite cauldrons

Also known as the 'Battersea' form. Comprise hemispherical or slightly globular-shaped bowls, made from a single piece of copper-alloy and upper bands of copper-alloy and/or iron sheet. Handles and rims are made of iron and are attached to the uppermost band.

- Group III - Globular cauldrons with narrow upstanding rims unperforated by rivet holes Also known as the 'Blackburn Mill' form. Globular, shouldered copper-alloy body with a narrow vertical rim unperforated by rivet holes. Handles are attached to the upper-portion of the copperalloy body.

- Group IV - Globular cauldrons with narrow upstanding rims perforated by rivet holes

Also known as the 'Elvanfoot' form. Globular one-piece copper-alloy bodies with narrow upstanding rims perforated by rivet holes which can be either evenly or unevenly spaced. An iron rim was presumably originally attached. There is no evidence on the copper-alloy body for handle attachment (the main difference from Group III) so it is thought handles were attached to the iron rim. The rivet holes on vessels assigned to this group are much further apart than those joining bowl and band for Group II vessels, meaning they are unlikely to be misidentified bowls of Group II vessels (Macdonald 2007, 96).

A further category of 'early cauldrons' is also identified for a small group which are later in date than Atlantic and earlier than the main identified groups of IA/ER cauldrons (see below; Appendix A). As the group is so small and quite varied, it is not yet possible to typify them as a group. 
A list of fragmentary remains from excavated sites that may originate from cauldrons and reported finds of ring handles was also compiled (Appendixes D \& E).

\section{FREQUENCY, SIZE, DISTRIBUTION AND CONTEXT}

\section{Frequency}

Fig. 4 shows the frequency of cauldrons by type (Table 1). It demonstrates that where they can be definitively assigned, Group II cauldrons are the most numerous, although the 17 Group II cauldrons from Chiseldon clearly skew the data. The second most numerous group is the projecting-bellied cauldrons (Group I), with Group III and IV roughly of similar frequency.

\begin{tabular}{l|r} 
Early & 5 \\
\hline Group I & 12 \\
\hline Group II & 28 \\
\hline Group III & 4 \\
\hline Group IV & 5 \\
\hline Late? & 5 \\
\hline Unknown & 18 \\
\hline & 77
\end{tabular}

Table 1: Frequency of cauldrons by type

\section{Context}

Fig. 5 shows the different contexts IA/ER cauldrons are found in (Table 2). Complete cauldrons are most likely to be found in watery contexts or as part of a hoard, frequently as the container for the rest of the objects. Again, the large number of cauldrons from Chiseldon skews the data in favour of hoards. As is demonstrated by Appendices D and E, fragments or bits of cauldrons are sometimes also recovered at settlements, perhaps remnants from dismantling and/or recycling or alternatively relating to specific fragmentation practice.

\begin{tabular}{l|r} 
Beach & 1 \\
\hline Burial & 4 \\
\hline Bog/Moss & 7 \\
\hline Hoard & 19 \\
\hline Lake/Loch & 9 \\
\hline River & 4 \\
\hline Settlement & 10 \\
\hline Unknown & 13 \\
\hline & 67
\end{tabular}

Table 2: The different depositional contexts for IA/ER cauldrons 


\begin{tabular}{c|c|c|c|c} 
& Group I & Group II & Group III & Group IV \\
\hline Beach & 0 & 0 & 0 & 1 \\
\hline Burial & 0 & 1 & 0 & 0 \\
\hline Bog/Moss & 3 & 0 & 0 & 3 \\
\hline Hoard & 1 & 18 & 0 & 0 \\
\hline Lake/Loch & 3 & 0 & 2 & 0 \\
\hline River & 0 & 5 & 0 & 0 \\
\hline Settlement & 0 & 3 & 0 & 0 \\
\hline Unknown & 5 & 1 & 2 & 1 \\
\hline Total & 12 & 28 & 4 & 5
\end{tabular}

Table 3: The different depositional contexts for IA/ER cauldrons by group

The wide range of different depositional contexts for cauldrons is perhaps surprising. Fig. 6 and Table 3 provide more detail, showing the different depositional contexts for each of the specific cauldron groups. Groups I, III and IV are predominantly found in watery contexts. In contrast, Group II cauldrons are found in many more different contexts.

Size

Figures 7 and 8 and Table 4 show the average maximum diameter, height and volume for all of the identified cauldrons. They demonstrate that projecting-bellied and early cauldrons are the largest. The other three types are slightly smaller and roughly the same size with an average volume of around 40 litres, although the average for Group IV cauldrons is exaggerated by the relatively large size of Abercairney.

\begin{tabular}{c|c|c|c} 
Type & $\begin{array}{c}\text { Average Diameter } \\
\text { (mm) }\end{array}$ & $\begin{array}{c}\text { Average Height } \\
\text { (mm) }\end{array}$ & Average Volume \\
& 521 & 326 & 51 \\
\hline Early Cauldrons & $($ Litres) \\
(Range) & $(375-640)$ & $(193-432)$ & (37-68)
\end{tabular}




\begin{tabular}{c|c|c|c}
$\begin{array}{l}\text { Group I } \\
\text { (Range) }\end{array}$ & $\begin{array}{c}579 \\
(335-710)\end{array}$ & $(270-495)$ & $(42-78)$ \\
\hline Group II & 408 & 250 & 40 \\
(Range) & $(280-680)$ & $(165-500)$ & $(26-79)$ \\
\hline Group III & 375 & 272 & 43 \\
(Range) & $(315-420)$ & $(216-309)$ & $(34-49)$ \\
\hline Group IV & 475 & 272 & 43 \\
(Range) & $(360-700)$ & $(210-375)$ & $(33-59)$
\end{tabular}

Table 4: Average dimensions of cauldrons by type

\section{Distribution}

Although when looked at as a whole there is a relatively even distribution of cauldrons across Britain and Ireland, when viewed by group some very distinct regional distributions are revealed (Fig. 9). For example, there is a clear concentration of Group II cauldrons below an imaginary line drawn between the Bristol Channel and the Wash. Group I projecting-bellied cauldrons are mainly distributed in northern Britain and Ireland. There is also an interesting concentration in northwest Norfolk. There are too few examples of identifiable Group III and Group IV cauldrons for a meaningful discussion of their distribution. Based on existing evidence, it is possible their distribution was similar to Group I cauldrons, but also including Wales.

\section{Discussion}

The validity of the cauldron typology is confirmed by distribution as clear regionality can be identified for Groups I and II. This regionality also partly explains differences in the diversity of contexts the cauldrons are found in. Prestigious or unusual metalwork from southern Britain (where Group II cauldrons are mainly distributed) are generally found in a wider variety of contexts in the later Iron Age than elsewhere in Britain (see Joy 2011; Gosden \& Garrow 2012). This distribution also has chronological structuring and consistency (as developed below). 


\section{Group I: Projecting-bellied}

The dating evidence for projecting-bellied cauldrons is relatively good (Macdonald 2007, 94; contra Macgregor 1976, 151). Radiocarbon dating of carbonised residues on the Balleymoney cauldron produced an uncalibrated date of $1842 \pm 25$ (UBA-10351). When calibrated with reference to the IntCal13 calibration curve (Reimer et al. 2013) using Version 4.2 of the OxCal calibration program (Bronk Ramsey \& Lee 2013), the determination obtained (at 95.4\% probability) was $87-107$ cal. AD (4.4\%) and 121-240 cal. AD (91.0\%), suggesting a date from the late first century - early third century AD.

Two cauldrons can be dated through associated artefacts: Carlingwark Loch and Santon. The Carlingwark Loch hoard is dated from the late first century - early second century AD (Manning 1972, 233). Spratling (2009 [1966], 70) has recently reviewed his dating of the Santon hoard based on the brooches to AD 40-70 (see also Manning 1972, 232; Spratling 1975, 207; Macdonald 2007, 94).

There are also strong continental parallels. Fox (1946, 43, Fn. 4) compares the Santon cauldron with an example from Emmendingen, Baden, illustrated by Déchelette (1914, Fig. 636). 'Emmendingen' cauldrons are also discussed by Raftery $(1984,234)$ and date from the first century BC into the Imperial period (Macdonald $2007,94)$. As is demonstrated by examples such as the cauldron from Crummackdale, Yorkshire, or the Wotton hoard, this form continued to be used for a number of centuries to at least the fourth century AD (Hawkes 1951, 185-8), although as Macdonald $(2007,94)$ makes clear, different, distinctively Roman manufacturing techniques were used and they are often of one-piece (Hawkes 1951, 188-189).

In summary, projecting-bellied cauldrons date from the mid-first century $A D$ to the second century $A D$ (Macdonald 2007, 94) and possibly into the third century AD in Ireland. Although some continental parallels date to as early as the first century $\mathrm{BC}$, there is no evidence that projecting-bellied cauldrons were deposited in the British Isles before the mid-first century AD.

\section{Group II: Globular composite cauldrons}

The cauldrons from Chiseldon have been dated through radiocarbon dating samples taken from the two cow skulls found with the hoard (see Table 5) (Barclay \& Grant in Joy \& Baldwin forthcoming). The digging of the pit 
has been modelled by Barclay and Grant as occurring sometime between 355-270 cal. BC (50.6\%) or 265-195 cal. BC (44.4\%), giving a range of $355-195$ cal. BC at $95.4 \%$ probability and they suggest that the hoard was deposited at some point during the mid-fourth century to early third century cal. BC, or the mid-third century to early second century cal. BC. This date is far earlier than previously thought for this type of cauldron (see discussion below).

\begin{tabular}{c|c|c} 
Laboratory Code & Object Number & Radiocarbon Age (BP) \\
\hline SUERC-45221 & $55 \mathrm{a}$ & $2197 \pm 22$ \\
\hline SUERC-45222 & $55 \mathrm{~b}$ & $2184 \pm 22$ \\
\hline SUERC-45223 & $117 \mathrm{a}$ & $2184 \pm 23$ \\
\hline SUERC-45224 & $117 \mathrm{~b}$ & $2223 \pm 25$
\end{tabular}

Table 5: Uncalibrated dates from Chiseldon

Two other cauldrons of this type can be dated by association: Baldock and Letchworth. The Baldock grave has been recently dated by Sealey $(2007,14 ; 2009,7)$ to c. 100 BC - 75 BC, but as Stead and Rigby $(1986,60-61)$ state, it could date as early as the late second century BC. The dating of the Letchworth cauldron fragment is based on stratified pottery which places its deposition somewhere between the mid-second and mid-first centuries BC (Moss-Eccardt 1965, 177; 1988, 88). Although attributed dates in previous discussions, the dating evidence for Spetisbury is not secure (Macdonald 2007, 95).

Possible continental parallels to Group II cauldrons (see Bochnak 2011, Fig. 2) have been discussed most recently by Stead and Rigby $(1986,59)$ and Moss-Eccardt $(1988,88-90)$. Discussing the Baldock cauldron, Stead and Rigby draw comparisons with the Brå cauldron, deposited in a pit in eastern Jutland and dating to the later third century BC (Klindt-Jensen 1953; Mortensen 1991, 375), as well as a series of cauldrons found in early Augustan burials in the Rhineland, Luxembourg and Belgium (Stead \& Rigby 1986, 59). Moss-Eccardt draws attention to the work of Eggers (1951, Tafel 2, Karte 10-11) who illustrates a number of different variants of cauldron which are very similar in form, particularly Eggers' Type 5. These are distributed throughout Denmark, northern Germany and southern Sweden. Since Eggers compiled his catalogue, numerous finds have 
been made in Germany between the Elbe and Weser rivers (Moss-Eccardt 1988, 88). A number of middle La Tène/late La Tène cauldrons of similar form were also found at Manching (Jacobi 1974) and La Tène (Vouga 1923, PI. XXVII). In Scandinavia cauldrons of similar form are relatively commonly found in cremation burials (see Moss-Eccardt 1988, 90 for examples).

Maguer et al. (2003) report on the discovery of an iron rim, ring handles and the upper band of a cauldron found in a pit at a settlement site at Vivoin, Pays-de-la-Loire, northwest France. The rim is quite large, $c$. $600 \mathrm{~mm}$ in diameter. Like the cauldron remains from Letchworth, the copper-alloy bowl was carefully removed before the iron remains were deposited in the pit. The Vivoin cauldron belongs to the so-called 'Gallic' type which is distributed from northwest and central France to central Belgium across to south-eastern Germany and Switzerland (Maguer et al. 2003, Fig. 14a). This type of cauldron dates from the second century BC - first century AD (Maguer et al. 2003, 230).

In summary, Group II cauldrons date from as early as the fourth century BC to the first century BC. Despite the fact that similar cauldrons are found in first century AD contexts on the Continent, there is currently no evidence that Group II cauldrons were used this late in Britain or Ireland but some of the simple globular cauldrons could conceivably date any time from the latter half of the first millennium BC to the second half of the first millennium AD (Spratling 1972, 235).

Group III: Globular cauldrons with narrow upstanding rims unperforated by rivet holes

The dating of this type has until recently been reliant solely on the cauldrons from Blackburn Mill (Macdonald 2007, 95). The Blackburn Mill hoard is dated to the late first or second century AD (Manning 1972, 232-233). The cauldron from the probable cremation burial at Welshpool can also be dated based on associated objects as well as a recent radiocarbon date of $1915 \pm 30 \mathrm{BP}(\mathrm{OxA}-17440)$ taken from a yew stave from the bucket which was also among the grave goods (Garrow et al. 2009, 119). When calibrated by Garrow et al. $(2009,119)$ this provided quite a wide date range (1-210 cal. AD) for the Welshpool grave but the dating of this grave group has also recently been discussed by Adam Gwilt (forthcoming 2014). Based on the associated objects in the grave, he concludes that the burial probably took place around $A D 120-150$, many of the artefacts in the grave being heirlooms, manufactured during the later first century AD. 
In summary, Group III cauldrons probably date from the late first to the second century AD.

\section{Group IV: Globular cauldrons with narrow upstanding rims perforated by rivet holes}

The dating evidence for Group IV cauldrons is unfortunately non-existent. Past discussions of possible dating evidence are neatly summarised by Macdonald $(2007,96)$ : “Unfortunately none of the Group IV cauldrons can be dated by either association or context. Burns' overly precise date of the first century AD for the Elvanfoot cauldron $(1969,34)$ has rightly been dismissed by Spratling for being based on insufficient evidence (1971, $111)^{\prime \prime}$

\section{Summary}

Group I, III, and possibly Group IV cauldrons (because they are so similar to Group III), are broadly contemporary being in use in the first and second centuries AD. The dating of Chiseldon shows that Group II cauldrons were in use for far longer than previously thought and were used from the fourth to first centuries BC. On current evidence, Group II cauldrons appear to have gone out of usage at least a century before the other groups suggesting there may not have been a considerable overlap of usage with the other groups, as previously thought. The small concentration of Group I cauldrons in northwest Norfolk represents a rare example of the usage and visible deposition of cauldrons in south Britain in the first century AD.

It is difficult to be certain how far these patterns represent the true distribution and date ranges of the different cauldron types. The data could be skewed by broader regional patterns of the deposition of prestige metal objects, relating to different social trajectories between southern Britain and northern and western Britain and Ireland during the first and second centuries AD. Group I cauldrons dating to the first century BC are known on the Continent and there seems no reason why they were not also used this early in Britain. Similarly, as is demonstrated by the presence of a small number of Group I cauldrons in northwest Norfolk, cauldrons were being made and used in southern England during the first century AD. Given that cauldrons similar to Group II cauldrons, such as the Vivoin cauldron, were made and used on the Continent until the first century $A D$, it is likely that there must have been some degree of overlap in the usage of Group I and Group II 
cauldrons. Nevertheless, as outlined above, the evidence also hints at strong regional preferences; with Group II cauldrons preferred in southern Britain and Group I cauldrons used in the north and in Ireland.

\section{UNCLASSIFIABLE CAULDRONS}

As with all typologies, a number of examples listed do not easily fit into this classification and it is worth briefly discussing them here with respect to their inclusion or not in the main catalogue (Appendix B). This is made more complicated as many finds are poorly recorded or come from watery deposits with no association, meaning that for dating purposes we are almost wholly reliant on comparative material and typologies (see above).

\section{Cauldrons $600 B C-400 B C$}

As was outlined in the introduction, there is an apparent hiatus in the deposition of cauldrons between the Early and Later Iron Ages (c. 600-200 BC). The re-dating of Group II cauldrons back to 400 BC goes someway to filling this chronological gap. A small number of other cauldrons defined here for simplicity as 'early cauldrons' can also be shown to date to the period from $600-400$ BC (Hawkes \& Smith 1957, 198; Gerloff 2010). As this period of absence has been of particular scholarly interest, it was thought worthwhile to list these early cauldrons as a separate catalogue (Appendix A).

The cauldron from the River Thames listed as 'London' has been traditionally assigned typologically to Hallstatt D (Hawkes \& Smith 1957, 191-194, Fig. 11). Labelled as 'Type Hundersingen-Narce' by Gerloff (2010, 371-2) and interpreted as a possible import (Hawkes \& Smith 1957, Fig. 12), it comprises a large, globular-shaped bowl manufactured from a single piece of copper-alloy. The cauldron has an infolding rim. Three rivet holes are visible on this rim indicating a point of handle attachment. Although the handles are now missing, a similar profile and arrangement of rim and handle attachment is seen on examples dating to Hallstatt D from the Continent (Bataille 2008, Fig. 18). A sheet fragment with in-turned rim from Luxulyan, Cornwall could also be an example of a cauldron of this type (Gerloff 2010, 371-372, No. 7).

Macdonald $(2007,95)$ assigns the Kyleakin cauldron to Group III based on the fact that the handles were originally attached to the body of the cauldron. This categorisation is uncertain as the profile of Kyleakin is very 
different from the examples listed in this group, being much flatter. A cautionary note must be made in terms of the profile because of the extent of the repairs to the bowl. Nevertheless, it is not thought that these repairs would have substantially altered its profile. Gerloff $(2010,378)$ assigns Kyleakin to its own group and compares its profile with continental cauldrons dating to Hallstatt D. It is also very similar in profile to a cauldron from a La Tène A cremation burial from Wallscheid, Rhineland, Germany (Verger 1997, 234, Fig. 14) and there is another close parallel from the site of La Tène (Vouga 1923, 81, PI. XXVII (1)). Looking at typologies of continental cauldrons (e.g. Bataille 2008, Fig. 18), the profile of Kyleakin fits most closely with examples dating to La Tène A or La Tène B. These have distinctive D-shaped handles. Unfortunately the handles on Kyleakin do not survive so its early date cannot be proven. The extensive repairs to the cauldron could also indicate that it was of some antiquity when it was deposited. A wooden keg originally containing bog butter from the same bog, although not necessarily associated, was radiocarbon dated producing a calibrated date of AD 246-346 (Earwood 1991, 233).

With no other parallels, the Drumlane cauldron is not certain to be of Iron Age date (Gerloff 2010, 378) but it is included here as it is generally regarded as being so (Raftery 1980; 1983; Loughran 1989). It is made entirely of iron, comprising numerous patches constructed in a series of bands in the same manner as Atlantic cauldrons, and is regarded as an intermediate piece, bridging Bronze Age techniques and the adoption of iron (Raftery 1980, 61; Gerloff 2010, 378).

Listed as late Iron Age by Macgregor (1976) and Raftery (1980), the cauldrons from Kincardine Moss and Ballyedmond have also been considered alongside the late Bronze Age - early Iron Age Atlantic category, often being seen as slightly later, possibly Hallstatt D and broadly contemporary with the cauldron from 'London' (see above) (Briggs 1987, 176; Northover in Cunliffe 1988, 58-60; Gerloff 2010, 186-189). It is certainly difficult to place both cauldrons securely into either the Atlantic or IA/ER sequences (Rynne 1960, 2; Briggs 1987, 176). Rynne $(1960,2)$ tentatively suggests a date in the seventh century BC for Ballyedmond. Briggs $(1987,176)$ draws on similarity of decoration with some of the Atlantic cauldrons described by Leeds (1930) to place them somewhere between the two main groups. Northover (in Cunliffe 1988, 58-60) argues for an early date based on the form of the rims and the layering of bands, one inside the other. Both, Northover argues, are more similar to Atlantic cauldrons. Northover (in Gerloff 2010, 189) also analysed the metal of both Kincardine and 
Ballyedmond and concludes that they are made of metal used during the Hallstatt $D$ and early La Tène periods. Gerloff $(2010,188)$ draws on decoration and cites similarities between the ring-and-dot motifs on the Kincardine panels with Hallstatt D decoration. She also sees parallels for both Ballyedmond and Kincardine with the 'London' cauldron and a cauldron from a multiple inhumation from the Dürnberg, near Hallein (Prüssing 1991, 76, No. 271), both date to Hallstatt D. Assigning the two cauldrons to their own class (Class B3), she concludes that these two cauldrons are “...contemporary with the latest phase of the Continental Hallstatt culture. Its beginning should, therefore, be dated to the earlier part of the sixth century but probably continuing well into the fifth century BC..." (Gerloff 2010, 188).

On the other side of the debate, Piggott $(1952-3,13)$, for example, states: “...it should be pointed out that the cauldron from Kincardine Moss, Stirling, is a particularly fine example of Fox's globular, composite type, and must surely be of Iron Age date and not, as sometimes inferred rather than stated, a member of the Late Bronze Age group of globular cauldrons". Macgregor (1976, 150-151) also places the pair in the later Iron Age because they are made of large pieces rather than patches. She also cites the decoration applied to the two cauldrons. She compares the ring-and-dot panels of Kincardine with 'Fox's casket ornament' and the patches on Ballyedmond are seen to date to the late first century AD. The raised bosses on both cauldrons, which resemble dome-headed rivets, are also compared with the Northern Boss style. Raftery $(1980,62-63)$ is more cautious, particularly as both cauldrons are single finds from bogs. He draws on similarities between the crescent-shaped patches on Ballyedmond and mounts found in the Birdlip mirror burial to give an early first century AD date for the cauldrons. The validity of this assessment has been questioned by Macdonald (2007, 95) but he nevertheless includes the two cauldrons in his catalogue of IA/ER cauldrons.

On the balance of the available evidence, because of the simple nature of the decoration on both cauldrons, it is possible to draw on parallels from both the late Hallstatt and later Iron Age, showing that the decoration is not useful for dating the vessels. The raised bosses could be also related to domed-rivets from both groups of cauldron. Like many IA/ER cauldrons, Kincardine and Ballyedmond are manufactured from three sheets, but with the exception of some of the projecting-bellied cauldrons, the pair are much larger than the rest of this group and their capacities are much more in-line with the Atlantic group. Unfortunately the exact nature of handle attachment is uncertain but it seems likely that the handles were attached at or near the rim. This is 
also much more in-line with Atlantic cauldrons. The unusual rim arrangement of both vessels could also be seen to echo Atlantic cauldrons. Metal analysis also points to an earlier rather than a later date. Finally, strong parallels from elsewhere dating to Hallstatt D can be drawn. In conclusion, with caution because of the lack of association, it seems more appropriate on the current balance of evidence to follow Briggs, Northover, and Gerloff and place Kincardine and Ballyedmond sometime in Hallstatt D, or very early in the La Tène period.

\section{Cauldrons of Probable Later Date}

Appendix $\mathrm{C}$ lists cauldrons which are probably later in date than the Iron Age or early Roman period. The large copper-alloy bowl from Awhirk is difficult to categorise because it is unfinished. It has an unusual profile which is most similar to Kyleakin, perhaps suggesting an early date. On the other hand, the small circular hole at the bottom and surface striations indicate that it was turned on a lathe which might indicate it is later in date than the IA/ER cauldrons that form the focus of this paper.

The deposition date of the rest of this group could be as late as the medieval period. They are discussed here because parts of these cauldrons have been re-used and are probably far more ancient (Raftery 1980, 60; Loughran 1989). Raftery $(1980,60)$ suggests Sessuegarry comprises a medieval dish, which forms a flat bottom, to which an ancient body has been attached. Kilmilhil also has a flat bottom and comprises numerous, roughly cut sections of copper-alloy held together by 'paper-clip' rivets. Again the topmost part looks older than the rest of the vessel, which is possibly medieval (Loughran 1989, 90). Although 'paper-clip' rivets are used for small repairs across the IA/ER cauldron group, they are not generally used to secure joins between component parts. Loughran $(1989,88-89)$ views the use of this technique on the Cloonfinlough, Dernaveagh Bog and Kilmilhil cauldrons as further evidence for the later date of these vessels. They are included in the main catalogue because surviving elements are typologically Iron Age with clear parallels. It is thought likely that the remains that survive originated in the Iron Age and may have been subsequently re-worked in a later period.

\section{Summary}

To summarise, a number of cauldrons can speculatively be dated to the period between $600-400 \mathrm{BC}$, in addition to the Group II cauldrons from Chiseldon dating from the mid-fourth century BC to the early second 
century BC. Of the others, 'London', Kincardine and Ballyedmond have very large capacities, in the region of 80 litres. Kincardine and Ballyedmond also have decorative plates or patches. Decoration on cauldrons is otherwise rare (although see below). Even within a conspicuous group of objects, these cauldrons stand out. Perhaps, during this period, cauldrons were only rarely in use, with large, elaborate examples reserved for particularly special occasions, before becoming more common with the manufacture of the Group II cauldrons. It is also possible in Ireland that parts of already ancient vessels were re-used during the medieval period to construct composite vessels. Exactly how these ancient vessels were recovered for re-use is unclear.

\section{TECHNOLOGY}

Cauldrons are rarely identical in form and manufacture, giving the impression of different formulations for the design of each one. Even when numerous cauldrons are found in the same context, such as Blackburn Mill and Chiseldon, the cauldrons are all different and they were often made using different techniques and technology. Elements of cauldron design are very sophisticated (Fig. 10). The paper-thin copper-alloy bowl acts as an extremely good conductor of heat. This is coupled with the use of iron rims and handles to provide strength and rigidity. Hawkes $(1951,181)$ notes that the diminished height to width ratio achieved by the shoulder carination of projecting-bellied cauldrons acted to expose a greater surface area to the fire, making it quicker to boil its contents.

\section{Copper-alloy}

Copper-alloy bowls must have been made in one of two ways: 'sinking' or 'raising' (Maryon 1938; 1949). Both processes start with a disc of cast copper-alloy. Discs could have been formed by casting direct into something like sand, or sometimes more formal stone moulds were made (see Cunnington 1920; Guilbert 1979, 187; Gwilt 2007, 307-308). The time and labour of making moulds could be offset by the time saved by starting the thinning processes from a truly circular disc.

Raising involves hammering the copper-alloy over a wooden former with the blows on the outside surface. The problem with this method is that it is not thought it would be possible to achieve the thinness of the copperalloy seen on cauldrons or the depth of the bowls (Loughran 1989: 23-24). This means that the most likely process was sinking. This is achieved by hammering the copper-alloy down into a hollow mould. Once the 
curvature was set, the bowl could be made deeper by hammering from the inside against a solid surface in a spiral pattern from the base upwards. Hammer marks revealing this process can be seen on a number of the cauldrons examined here (see Appendix B).

In some instances a small plugged hole is found at the bottom of cauldron bowls. It is thought that this is evidence for spinning or final finishing on a lathe. Although this is generally viewed as an attribute of cauldrons from later periods (Hawkes 1951, 185, 188-189), the pole lathe was certainly in use by the later Iron Age (Tylecote 1962, 150) and lathes could also have been used in the final finishing process after the bowl had been shaped by hammering (Tylecote 1962, 150; Loughran 1989, 25).

Iron

Owing to the poor survivability of iron, most discussions of technology have concentrated on the copper-alloy components (e.g. Loughran 1989, 23). Quanyu Wang (in Joy \& Baldwin forthcoming) has analysed the iron components of the cauldrons from Chiseldon. Her analysis reveals the sophistication of the techniques used. For example, some of the rims were attached to the upper band hot. The rim was then quenched in water causing it to contract and fit firmly on to the uppermost band. This is the same technique used to fit iron tyres onto chariot or cart wheels. In the case of the cauldrons, we are dealing with metal-to-metal rather than metal-to-wood as is the case with cart wheels. Wang also found that iron from different sources was used to make different components of the same cauldron. For example, the rim of one cauldron was found to have a higher phosphorous content than the upper band. This would have made it more pliable when hot and harder when it cooled down; both important properties for attaching the rim when hot and providing rigidity to the object.

\section{DECORATION}

A number of cauldrons have a form of bossed decoration which has been added after final burnishing by punching from the inner wall to produce a bossed effect on the outside (Loughran 1989: 26). A more pronounced form of bossed ornamentation is seen on the cauldrons from Kincardine Moss and Ballyedmond which have large domed-bosses running along the seam between the bowl and the shoulder. The domedbosses are not actually rivets; they are purely ornamental and were raised by hammering from the inside 
surface. A series of small rivets can be seen in between each boss and these are the actual means of securing the join. The Spetisbury cauldron has large domed-rivets in a similar position creating a very similar decorative effect.

Two of the early cauldrons, Kincardine Moss and Ballyedmond, have decorative patches. Covering the join of the upper band of Kincardine Moss is a rectangular plate with 53 raised ring-and-dot motifs arranged in a geometric pattern. On Ballyedmond there is a crescent-shaped patch decorated with a series of small raised dots and lines delineating a pattern arranged around the crescent shape of the patch. The area around each handle on the Carlingwark cauldron is also decorated with a series of lines comprising small raised rivets. On some cauldrons particular time and effort has also been invested in repair patches of novel form such as sshapes which can be quite decorative. Interestingly, many of these are located on the inside and would not have been visible when the cauldron was full.

Set against this relative paucity of decoration, the cauldrons from Chiseldon are exceptional (Joy \& Baldwin forthcoming). Bands of at least two of the cauldrons have scalloped edges and at least four have decorative patches. Finally, three of the cauldrons have decorative repoussé mounts located immediately below the handles. The copper-alloy mounts on cauldron SF11 are decorated with raised fin and lobe motifs forming a design in the pattern of an extended lyre-loop (Joy 2008, Fig. 5.3). The iron mounts from cauldron SF7 are in the form of a cow's head with elongated ears (Fig. 11). Only one of these survives but enough remains of the opposing side of the cauldron to indicate it was similarly decorated. When it was suspended each half of the ring handle would have given an impression of the cow's horns.

The cow's head decoration from Chiseldon is exceptional and no other British cauldron is decorated in this way. This is perhaps surprising given that there are many well-known examples of Late Iron Age vessels that are adorned with human or animal heads, especially ox/bull heads, on escutcheons and mounts on buckets and on the handles of smaller copper-alloy bowls. Most of these objects date to the first-century BC, continuing into the Roman period, but as we have seen, the Chiseldon deposit could be as early as the fourthcentury BC. Possibly the best-known cauldron from the Continent decorated with animal heads is the thirdcentury BC cauldron from Brå near Horsens in eastern Jutland, Denmark (Mortensen 1991: 375). The bronze 
attachments of each of the three handles are decorated with owl's heads. There are also six bulls' heads which acted to stop the handles from damaging the bowl. The Chiseldon example demonstrates that zoomorphic decoration was in use in Britain much earlier than previously realised.

The final decorative patch from Chiseldon is perhaps the most remarkable (Fig. 12). It comprises an iron mount with a raised pattern in the so-called 'Waldalgesheim' or 'Vegetal' style (Jacobsthal 1969 [1944]) and previously termed Stage II art by Stead (1996 [1985], 22). The Vegetal Style dates to the later fourth century BC and the style comprises flowing tendrils. It is widely distributed from Hungary to England (Stead 1996 [1985], 22-25). The flowing tendril design on this object ends in a motif more reminiscent of Jacobsthal's 'early' style.

Objects decorated in the Vegetal style are extremely rare from Britain and there are no more than a handful of examples, including the shield from Ratcliffe-on-Soar, Nottinghamshire (Watkin et al. 1996). There are no parallels from Britain in iron which use raised decoration. The closest parallels are from the Continent, in particular a series of decorated sword scabbards from the Paris basin (Ginoux 2009, figs. 78-79).

\section{DISCUSSION: USE AND SIGNIFICANCE}

Very little work has been done to examine how cauldrons were used or what they were used for. Other than Smith (1906-7; 1914-15), who interprets some cauldrons as ancient water clocks because of a central hole in the bowl which we now interpret as evidence for lathe turning (see above), it is presumed cauldrons were used in the preparation and serving of food and drink. Discussion of their use and significance in the various catalogues is almost non-existent, perhaps because it is viewed as self-evident.

There is some discussion of the significance of cauldrons in the general literature. For example, Cunliffe (2005, $94,154,456-8,460,462,493,535-536)$ discusses later Atlantic cauldrons in the context of Early Iron Age exchange networks but other than noting the presence of a cauldron in the Baldock burial, does not mention IA/ER cauldrons. Other general discussions tend to concentrate on descriptions of cauldrons in Irish and Welsh early medieval texts, relating their mythical roles in feasts and as magical objects associated with resurrection and sacrifice to their potential social significance during the Iron Age (e.g. Ross 1967; Green 1998). 
There has been more discussion of Atlantic cauldrons. The dominant interpretation of Atlantic cauldrons is that they were used in the preparation of meat. Other interpretations include their use in the serving of alcohol and even drugs (Armada 2008, 152; 2011, 168). Their large size and associations between cauldrons and artefacts such as flesh-hooks have also been interpreted as evidence for the ceremonial and social importance of ritual feasting for the elite of the Atlantic later Bronze Age (Gerloff 1986, 87-88, 96-97; Needham \& Bowman 2005, 94; Bowman \& Needham 2007, 97-98); for example Armada $(2011,168)$ suggests

"...their use as symbols of the abundance, wealth and redistributive power of the chief who owned them".

Here an extended discussion is presented to consider not what IA/ER cauldrons mean, but what they do; how social practices, specifically feasts and depositional events, were enacted through their material properties.

\section{How were cauldrons used?}

A number of features of cauldrons can be inferred from the data collected in this catalogue. These may seem obvious but when data are limited, observation of this type can be important. Many of the repairs observed on the cauldron bowls act to keep them watertight. We can then infer that the cauldrons held some form of liquid, or substance including liquid. Repairs to handles and their attachments to cauldron bodies imply that suspension via the handles was also important. Finds of iron chains and frames (Piggott 1952-3; Savory 1966; Manning 1983) provide further material evidence for suspension of vessels. Suspension could also have been achieved using perishable materials which do not survive. Finally, many cauldrons have black oxidised layers (soot) on the outside surface. This evidence combined together implies that cauldrons were suspended over an open fire to heat or warm the substance contained within. Depending on the foodstuff or drink being prepared, and the ratios of solids to liquids, cauldrons could be used to prepare dishes by stewing, braising or boiling (Dan Stansbie pers.comm 2013). Their large capacities also mean that they can be used to serve and/or warm large quantities of drink, possibly alcoholic (see below).

Continued suspension once cooking or warming was completed, would facilitate the serving of food or drink. Cauldrons are too big and cumbersome to be easily moved when full. Theoretically this could have been achieved by inserting a wooden or metal pole through both handles allowing two individuals, one at either end, to carry them. It is impractical to consume food or drink directly from a cauldron. This means that it 
would have to be dispensed into vessels or platters and then distributed. The swivel mechanism seen on some of the cauldron handles from Chiseldon allows the vessel to be tipped when suspended, meaning that large quantities of food could be transferred relatively easily (Joy in Joy \& Baldwin forthcoming). Wood remains also recovered from Chiseldon could represent utensils and serving vessels made of wood which were used alongside cauldrons to prepare and serve food (Cartwright in Joy \& Baldwin forthcoming; see also Earwood 1993).

A very few cauldrons have been found with organic residues adhering to their surface or trapped in the overlap between bands. These residues provide clues as to what was being prepared and served in them. The most extensive analysis of residues to date has been conducted on the Chiseldon cauldrons and residue samples taken from most of these contain animal fats (Steele in Joy \& Baldwin forthcoming). This evidence is interpreted to indicate that the Chiseldon cauldrons were used to prepare and serve meat stews. One cauldron has been found to contain the remains of an alcoholic drink: residues extracted from the bottom of the cauldron from Eberdingen-Hochdorf, Kreis Ludwigsberg, Baden-Württemberg, southwest Germany contained honey, probably the remnants of a honey-mead (Biel 1987, 126).

Building on this evidence, we can infer more information about the context of the use of cauldrons. Many have very large capacities. The cauldron from Hochdorf could hold 500 litres. The cauldrons examined here had more modest capacities, ranging from 30-80 litres (Fig. 8). Even taking into account the fact that they are unlikely to have been filled to the brim and probably only ever two-thirds full, even the smallest cauldrons still probably contained 20 litres. This is a substantial quantity of food or drink. With the exception of large ceramic storage jars, vessels of this size are otherwise rare in Iron Age Britain and Ireland. So-called pottery cauldrons represent scarce finds, for example from south Essex. One of the finest examples came from what is known as the 'cauldron pit' from Ardleigh, Essex (Sealey 1999, 117). Large wooden cauldrons are also known from Ireland (e.g. Raftery 1983, Fig. 168). Although these obviously could not be heated over a fire, it would have been possible to cook food or heat liquid by placing hot stones inside them. Finally, objects such as buckets and amphora are present but these were used primarily for serving and storing drink rather than preparing food. 
One final observation is the number of repairs present on cauldrons. Indeed it is rare to find a cauldron without at least one repair and many have very extensive, overlapping repairs. Although some of the repairs could have been made at the time of manufacture (Joy \& Baldwin forthcoming), most were added throughout the life of the object. The fact that so much time was invested in their repair indicates that they were valued artefacts and also suggests they led long social lives.

Feasting

Given the relative scarcity of cauldrons (Raftery 1980,65) and their large capacities, they were probably not used every day. Rather they were used in the preparation and serving of food and drink at larger social gatherings, probably at feasts, but what does this actually mean in terms of informing us about the social usage and significance of cauldrons?

Feasting has been a popular recent topic in archaeology particularly with the publication of three influential edited volumes on the subject (Wiessner \& Schiefenhövel 1996; Dietler \& Hayden 2001; Bray 2003) prompted by major works in social anthropology (e.g. Lévi-Strauss 1968; Goody 1982). At their heart feasts involve the creation and maintenance of social relationships and can be used to redistribute wealth, mobilise labour, create alliances between or exclude different groups, celebrate marriages, commemorate deaths and compensate for transgressions (Hayden 2001, 30). As objects used during feasts, cauldrons help facilitate these activities and that is where much of their significance and value derives.

The importance of feasting to Iron Age society is increasingly being recognised (e.g. Arnold 1999; Dietler 1996; 2001). The work of Michael Dietler who has examined feasting in the Early Iron Age of western Europe has been particularly influential (see Poux 2004; Ralph 2007; Fitzpatrick 2009). Dietler (1996; 2001) identifies three different patterns of feast which he calls Entrepreneurial or Empowering, Patron-role and Diacritical. Empowering feasts allow people or groups to acquire prestige without necessarily requiring the existence of fixed social hierarchies. By hosting a feast, debts or obligations are passed on to guests thus making feasts arenas for negotiations of social influence, but empowering feasts can also be viewed as celebrations of community identity (Dietler 2001, 76-77). Patron-role feasts occur when there is an expectation or obligation for the social elite to host feasts and there is no expectation for equal reciprocation. Diactritical describes a 
group of feasts where certain sectors of society choose to consume different types of food and drink and/or consume food and drink in different ways as a means to demonstrate their difference from others.

Andrew Fitzpatrick (2009) has recently related Dietler's categories to archaeological evidence to try and identify different feasting patterns. Of particular relevance here is his discussion of the late second century $\mathrm{BC}$ burial from Baldock, Hertfordshire, which contained amongst other things, two wooden buckets, two iron firedogs and a cauldron (Fitzpatrick 2009, 395-397). In this instance, Fitzpatrick argues the cauldron and other objects in the grave act to demonstrate the grave-occupants role as an 'organiser' of patron-role feasts. This is not the only way in which cauldrons could be represented at feasts. Indeed in the context of the IA/ER corpus, very few of which are found in graves, it is unusual, even when the biasing effect of a general lack of Iron Age graves is taken into account. Much more likely, cauldrons were used in entrepreneurial or empowering patterns; at least that is what we can see from the depositional evidence as is best exemplified by the remains from Chiseldon, which appear to represent the symbolic remains of a communal feast. The fact that many cauldrons were deposited in watery contexts, presumably as gifts to the gods made by communities or groups, also adds weight to this interpretation. These differences also highlight possible changes in the use and significance of cauldrons through time and according to region.

\section{Deposition}

Fragments or bits of cauldrons are sometimes recovered at settlements but most were deposited complete or with the rim and handles removed prior to deposition. The fragile nature of cauldrons could skew the data in favour of contexts involving single episodes of deposition, which would minimise potential pre-depositional damage to artefacts. An alternative view, and the view subscribed to here, is that the fact that some objects were deposited intact rather than broken up should be seen as highly significant. As has been demonstrated, cauldrons were important objects and were involved in important social events. A particular kind of decommissioning may have demanded that these objects were taken out of society. Some evidence in support of this is found on sites such as Maiden Castle where components appear to have been removed and selected for deposition, particularly handles and rims, while other cauldron parts, particularly copper-alloy sheet, may have been recycled or re-used (Sharples 1991, 160-165). If this is so, then we should ask why some cauldrons are deposited intact. Perhaps in these instances the role of cauldrons as containers or as redistributive 
receptacles is again drawn upon in deposition. Their role in redistributive, life-event and/or religious ceremonies, or the preparation, containment and serving of special foodstuffs, could also account for why cauldrons were seen as appropriate objects to be deposited in watery contexts and dry land hoards. For example, in some hoards such as Carlingwark, the objects are placed inside a cauldron prior to deposition. It is likely there is more significance to this practice than simply the use of the cauldron as a convenient container. Rather it is argued that the use of cauldrons as receptacles for symbolic foodstuffs is drawn upon in deposition and they are instead used as containers for another kind of offering, this time to deities or ancestors rather than attendees at feasts.

\section{Summary}

In summary, cauldrons would have taken centre-stage at feasts suspended above hearths but they were not always necessarily used in the same way. If some individuals were served the contents of cauldrons and others not, social differences could have been emphasised. Alternatively, if everyone served themselves, either directly or from large bowls or platters, communal identity is underlined. A mutually-constitutive relationship between feasting objects and patterns of feasting can be observed, with the form of feasting objects dictated by but also influencing feasting patterns.

\section{CONCLUSIONS}

Through a re-examination of IA/ER cauldrons, a little studied but important artefact class, typology and chronology have been re-addressed and the social significance of cauldrons for Iron Age society has been highlighted. IA/ER cauldrons can be divided into two broad types (projecting-bellied and globular) and four groups. New data on dating demonstrates that these four groups are not broadly contemporary as previously thought. Group II cauldrons were made and circulating in use between the fourth to first centuries BC. The other three groups probably all date to the first and second centuries AD although dating evidence, especially for Group IV cauldrons, is still relatively sparse. Group I cauldrons are largely confined to north Britain and Ireland, with a small concentration of objects in northwest Norfolk. Group II cauldrons are distributed below an imaginary line drawn between the Bristol Channel and the Wash. Too few examples of Group III and IV cauldrons are known for too much significance to be drawn from current distribution patterns but their ancient distribution may have been similar to Group I cauldrons though also extending into western Britain, 
especially Wales. A perceived absence of cauldrons between 600 and $200 \mathrm{BC}$ has been called into question through the re-dating of Group II cauldrons to as early as $400 \mathrm{BC}$ and the identification of a small number of cauldrons dating to the period $600-400 \mathrm{BC}$. Detailed examination of the technology of manufacture and physical evidence of use and repair indicates that cauldrons are technically accomplished objects requiring great skill to make. Many have been extensively repaired, hinting that they may have been used for some time. It is argued that owing to their large capacity cauldrons were not used every day but were instead used at large social gatherings, specifically at feasts. The social role of feasting has been explored and it is argued that cauldrons derive much of their significance from their use at feasts, making them socially powerful objects, likely to be selected for special deposition when their material properties as containers are transformed, establishing relationships between people, gods and ancestors.

\section{ACKNOWLEDGEMENTS}

First I would like to thank the Leverhulme Trust for providing funding for much of the research conducted to write this paper. I would also like to thank colleagues at the British Museum and Wessex Archaeology who have worked with me on the publication of the Leverhulme Trust funded project examining the cauldrons from Chiseldon, Wiltshire. I have relied heavily on information derived from Chiseldon to produce this paper. Alex Baldwin in particular has worked tirelessly excavating and conserving material from the site. I would also like to thank Hayley Bullock, Caroline Cartwright, Andrew Fitzpatrick, Hazel Gardiner, Marilyn Hockey, Jamie Hood, Philippa Ryan, Val Steele and Quanyu Wang. Eamonn Kelly and Eamonn McLoughlin of the National Museum of Ireland provided the radiocarbon date of the Balleymoney cauldron and kindly allowed me to publish this date here.

I would also like to thank the museum curators and other staff who assisted me during my research visits. Adam Gwilt, Evan Chapman and Mary Davis provided support and references and Jody Deacon helped me to examine the cauldrons at the National Museum, Cardiff. Special thanks must also go to Fraser Hunter, Alice Blackwell, Jim Wilson and lan Leins who helped me to examine and record cauldrons at the National Museum of Scotland, Edinburgh, when I had a broken elbow. Thank you also to: Mary Cahill, Eamonn Kelly, Paul Mullarkey, Isabella Mulhall and Margaret Lannin from the National Museum of Ireland, Dublin; Tim Padley of Tullie House Museum, Carlisle; Andrew Parkin, Great North Museum, Newcastle; Imogen Gunn, Museum of 
Archaeology and Anthropology, Cambridge; Tim Pestell, Norwich Castle Museum, Norwich; Virginia Smithson and Ben Roberts, British Museum, London; and Keith Fitzpatrick-Matthews, Letchworth Museum. Thank you also to Julia Farley for locating and providing information about the Walthamstow cauldrons and to Julia Farley and Matthew Hobson for investigating the context of the discovery of the cauldron from Sedgeford. Thanks to Lois Armada, Andrew Fitzpatrick, Peter Northover, Mansel Spratling and Dan Stansbie for providing me with valuable references and to Stephen Crummy, Saul Peckham and Craig Williams for their work on the illustrations and photography. Adam Gwilt, Fraser Hunter, Mansel Spratling and Neil Wilkin kindly read and commented on previous drafts of this paper. Finally, special thanks to Miriam Joy and Florence Joy for their help and assistance throughout. All errors remain my own.

APPENDIX A: CAULDRONS PROBABLY DATING TO c.600 BC $-400 \mathrm{BC}$

\section{Ballyedmond, Co. Galway, Ireland}

Location: National Museum of Ireland, Dublin (NMI 1961: 180)

Dimensions: Maximum diameter: 630mm; Rim diameter: 420mm; Height: 432mm

Type: Gerloff Class B3

Description: Globular copper-alloy cauldron made from three sheets. A hemispherical bowl is riveted to an upper band which comprises two rectangular sheets joined by a single row of rivets. Securing the join between the bowl and band are a series of equally spaced round-headed rivets. Between each pair of rivets is a raised small square boss formed by hammering the metal from the inside. The upper band curves inwards towards the top. On top of this band is a flat strip of copper-alloy with a central, rounded groove. According to Raftery (1983: 208), this is probably a later addition to the cauldron as the rivets securing it are larger and have different spacing. The handles are missing but two concentrations of rivets defining rectangular areas, diametrically opposite one another, probably indicate their original positions. In total there are 30 repairs: 20 patches and 10 'paper-clip' repairs. The patches vary in form and there are square, rectangular, oval, leaf and S-shaped examples. Most are on the inside surface but six are also attached to the outside. Near the rim are two large crescent-shaped patches one on the inside, the other on the outside of the cauldron. These have been riveted and are decorated with raised ornament.

Discovery: Found about $1.2 \mathrm{~m}$ below the surface of a bog

References: Rynne 1960, 1-2; Raftery 1963, 126, PI. XIII; Raftery 1980, 58, No. 2, Figs. 3-4.1 \& 11.2; Raftery 1983, 208-9, No. 556, Fig. 167; Raftery 1984, 231-2. 


\section{Drumlane, Co. Caven, Ireland}

Location: National Museum of Ireland, Dublin (NMI1887: 3)

Dimensions: Maximum Diameter: 375mm; Diameter at mouth: 337mm; Height: 193mm; External Diameter of Handle:

$80 \mathrm{~mm}$

Type: Globular

Description: Made entirely of iron, the bowl is formed of a number of sheets arranged in concentric rings and joined by

large dome-headed rivets. The handles are made of twisted square-sectioned bar metal. These are secured to the vessel by two rectangular-shaped escutcheons through a loop situated above the level of the rim.

Discovery: Found at a depth of $75 \mathrm{~cm}$ while cutting turf on the shore of Drumlane Lough.

References: Raftery 1980, 57, 68 f., Figs. 1.2; Raftery 1983, 207, No. 555, Fig. 166; Raftery 1984, 9, 228, 231, Fig. 4, 3;

Loughran 1989, No. 16.

\section{Kincardine Moss, Stirlingshire, Scotland}

Location: National Museum of Scotland, Edinburgh (DU1)

Dimensions: Maximum diameter: 640mm; Height: $410 \mathrm{~mm}$

Type: Gerloff Class B3

Description: Large copper-alloy globular bowl and a wide upper band comprising two copper-alloy sheets. The two main sections are joined by small rivets. Between each pair of rivet is a large circular raised boss which has been formed by hammering from the inside. From a distance these resemble large dome-headed rivets but they are purely decorative. The areas of overlap of the band are concealed by two rectangular decorative plates. These are both decorated with $50+$ raised rings-and-dots. The handles are missing. There are two diametrically opposed areas on the rim where they could have been attached but neither attachment survives. Hammer marks can be seen across the surface of the vessel, these have been hammered from the outside. The upper-part of the cauldron is an unusual arrangement. Running along the inside of the mouth is a hollow copper-alloy tube. On the outside of the mouth is another hollow tube formed by folding over the top-most part of the upper band. The cauldron is in excellent condition and there is no evidence of repair.

Discovery: Found at Kincardine moss in 1768

References: Anderson 1884-85, 313, Fig. 2; Burns 1969, 32-3; Piggott 1970: 21, No. 106; Raftery 1984, 232, 328; Hunter 1997, 110, 125.

\section{Kyleakin, Skye, Scotland}

Location: National Museum of Scotland, Edinburgh (DU5) 
Dimensions: Diameter at mouth: 450; Height: $236 \mathrm{~mm}$

Type: La Tène A or La Tène B?

Description: Globular copper-alloy cauldron with a short vertical neck at the top where the rim would have been secured. There are no rivet holes in this area which implies that if an iron rim originally existed, it was folded over onto the lip and applied hot or hammered to make the joint secure. The attachments for the two handles are visible on the upper body of the cauldron. These comprise three large rivet holes arranged to form the points of a shallow isosceles triangle. Below this are a further 4 rivets arranged to form the corners of a small square. A small square section of metal is secured by these rivets to the inside of the cauldron. The arrangement is the same on the opposite side but some of the holes have been filled.

The cauldron has been much repaired. It is difficult to unpick the stratigraphy of the repairs to the base as they are so extensive. A small disc may once have been secured to the main body by rivets but it is difficult to be certain if it is a repair or was part of the original manufacture as so many subsequent repairs have been made. Some of the repairs to the side of the cauldron have at least 3 layers. Patches of copper-alloy of various shapes and sizes were used. These were secured with rivets. There are also at least 10 'paper-clip' repairs.

Discovery: Found before $1884,2.3 \mathrm{~m}$ below the surface in peat, apparently in the vicinity of several kegs of bog butter. References: Anderson 1884-85, 311, Fig. 1; Burns 1969, 32-3; Spratling 1971, 112; Macgregor 1976, 170, No. 306; Raftery 1984, 232, 328; Loughran 1989 No. S8.

\section{London, England}

Location: British Museum, London (P\&E 1859.0122.13)

Dimensions: Diameter at mouth: 510mm; Height: $360 \mathrm{~mm}$

Type: 'Hundersingen-Narce'

Description: Large copper-alloy cauldron. The substantial part of one side is missing but otherwise the metal is in good condition. The top has been reinforced at the top by conservators with a flat strip bridging the broken area at the rim. The hemispherical bowl comprises of a single sheet and has a flattish base. Opposite the missing section is a triangular arrangement of rivet holes indicating where the handle was attached.

Discovery: Found in the River Thames before 1859

References: Hawkes \& Smith 1957, 191, Fig. 11A.

\section{APPENDIX B: IRON AGE AND EARLY ROMAN CAULDRONS}

\section{*Abercairney, Perthshire, Scotland}


Location: Perth Museum (IE/1946)

Dimensions: Maximum diameter: 670-700mm"; Rim diameter: 590-640mm; Height: 375mm

Type: Globular (Group IV)

Description: Formed from a single sheet of copper-alloy. In good condition except for some dents. The iron rim and handles have not survived. It has two 'paper-clip' repairs'iii. Oval punch marks are visible across the entire surface.

Discovery: From a bog on the Abercairney Estate, discovered before 1946

References: Burns 1969, 31-2; Spratling 1971, 111; Macgregor 1976, 170, No. 300; Hunter 1997, 125; Loughran 1989, No.

S3.

\section{Baldock, Hertfordshire, England}

Location: Letchworth Museum

Dimensions: Maximum diameter: 680mm; Rim diameter: 660mm; Height: 500mm

Type: Globular (Group II)

Description: Fragmentary. Comprising parts of an iron rim, two iron ring handles and parts of an upper band of copper-

alloy. At the bottom of this band are a number of dome-headed rivets and the remains of a copper-alloy bowl. The handle attachments both survive and are comprised of three linked, semi-circular iron loops. 4 waisted copper-alloy knobs, two located at each side of both handle attachments, acted as 'stops' to prevent the heavy iron handles from damaging the bowl.

Discovery: From a cremation burial with the cauldron at the centre of the grave.

References: Stead 1971, 251; Stead \& Rigby 1986, 55-9, Figs. 21, 23; Loughran 1989 No. E6.

\section{Ballymoney, Co. Antrim, N. Ireland}

Location: National Museum of Ireland, Dublin (NMI 1903: 251)

Dimensions: Diameter at rim: $710 \mathrm{~mm}$; Height: $495 \mathrm{~mm}$

Type: Projecting-bellied (Group I)

Description: The hemispherical copper-alloy bowl has pronounced shoulder carination. The upper-tier comprises two rectangular sheets which are secured by rivets to the inside of the bowl. The sheets overlap by $120 \mathrm{~mm}$. At the very centre of the bottom of the base is a small disc riveted in place. According to Raftery (1983: 210), the patination of this disc is different from the rest of the base indicating that it is an ancient repair. Rectangular and D-shaped patches are also present, as well as a 'paper-clip' repair.

Discovery: From a bog, found $6 \mathrm{~m}$ below the surface 
References: Armstrong 1923, 25 Fig. 13.2; Raftery 1980, 59, No. 4, Figs. 7 \& 12.1; Raftery 1983, 210, No. 558; Raftery 1984, 234, 316, PI.75; Macgregor 1976, 170; Loughran 1989 No. 1; Gerloff 2010, 379.

Metal Analysis: $\quad$ Sample Area 1 (lower): $\quad$ CU 86.38\%; SN 12.13\%; AG 0.4\%; ZN 0.13\%; AS 0.05\%; SB 0.05\% Sample Area 2 (upper): $\quad$ CU 87.82\%; SN 11.2\%; AG 0.04\%; ZN 0.12\%; AS 0.01\%; SB 0.05\%

Radiocarbon date: From carbonised residues - 1842 25 BP (UBA-10351) 87-107 cal. AD (4.4\%)

$121-240$ cal. AD (91.0\%)

Unpublished. Information provided by kind permission of Professor Eamonn Kelly, National Museum of Ireland, Dublin.

\section{Battersea, London, England}

Location: British Museum, London (P\&E 1861.0304.5)

Dimensions: Maximum diameter: 375-395mm; Height: 197mm

Type: Globular (Group II)

Description: Copper-alloy globular-shaped bowl. Remaining rivets and rivet holes indicate that the cauldron originally had an upper band. According to Smith (1909: 148), 100 years ago there were still traces of iron in this area, indicating that the band was probably made of iron. The handles and rim are also missing. Close to the upper edge on the inside of the bowl are two small repair patches.

Discovery: Found in the River Thames at Battersea

References: Smith 1906-7, 328-9, PI. 4 opposite 326; Smith 1909, 148; Spratling 1972, No. 426; Loughran 1989, No. E7.

\section{Bewcastle, Northumberland, England}

Location: Tullie House Museum, Carlisle (CALMG: 1947.51)

Dimensions: Internal diameter at mouth: 620-640mm; Height: $480 \mathrm{~mm}$

Type: Projecting-bellied (Group I)

Description: Projecting-bellied copper-alloy cauldron made from three sheets. A hemispherical bowl with pronounced shoulder carination is riveted inside an upper band which comprises two rectangular sheets joined by two inward slanting columns of rivets. The bands overlap by $110 \mathrm{~mm}$. A third vertical column of rivets situated to the right of the overlap of metal pierces a single sheet of copper-alloy only and is purely decorative. Four rivet holes forming the corners of a square in both areas of overlap indicate the position of the iron? handles (now missing). The rim is missing but was attached by means of six clips of diamond-shaped cross-section secured to the top of the upper band. Modern conservation makes it difficult to quantify repairs but the vessel has been extensively repaired using rectangular and leaf-shaped patches riveted to the inside of the vessel. Three patches are located in the centre of the bowl and five along its shoulder. A further three 
repairs are visible on the upper band. More could be obscured by the conservation work. In addition there are two 'paperclip' repairs. Overall the vessel is in good condition.

Discovery: Found in a bog ("The Black Moss") at High Grains, Bewcastle during peat-cutting in 1907

References: Smith 1906-7, 329; Feacham 1965, 229, PI. 11b; Spratling 1971, 111; Macgregor 1976, 170; Loughran 1989 , No. E14.

\section{Blackburn Mill I, Berwickshire, Scotland}

Location: National Museum of Scotland, Edinburgh (DW87)

Dimensions: Diameter at mouth: $386 \mathrm{~mm}$; Height: $254 \mathrm{~mm}$

Type: Globular (Group III)

Description: Globular copper-alloy bowl. The iron? handles and rim are missing. Two diametrically opposed groups of three rivet holes near the top of the bowl, forming a triangle, indicate the position of the handles. No handle fittings survive.

There is extensive evidence of repair. Three patches are present in the area of the handle attachment and there are two 'paper-clip' repairs. The base has been repaired with seven patches.

Discovery: Part of a hoard of local and Roman metalwork found by labourers sometime before 1852 . According to Newton (1852: 43-44), one cauldron was placed upside down above the other with the other objects contained inside. The original context of deposition is unclear. The objects were found while digging a drain for a peat moss, which was probably once a loch (see Macdonald 1976: no. 301).

References: Newton 1852; Smith 1914-15, 87, 93; Curle 1931-2, 310, 313-314, Fig. 21; Hawkes 1951, 183, Fig. 47; Piggott 1952-3, 40 No. B1, Fig. 7; Spratling 1971, 112; Macgregor 1976, 151, 170, No. 301; Loughran 1989 No. S4.

\section{Blackburn Mill II, Berwickshire, Scotland}

Location: National Museum of Scotland, Edinburgh (DW88)

Dimensions: Diameter at mouth: 315mm; Height: $216 \mathrm{~mm}$

Type: Globular (Group III)

Description: Globular copper-alloy bowl. The iron? handles and rim are missing. Two diametrically opposed groups of three rivet holes near the top of the bowl, forming a triangle, indicate the position of the handles. No obvious fittings survive although staining in this area indicates they were probably iron. At the centre of the base is a small perforation which has been plugged indicating the vessel was spun or turned on a lathe. There is no evidence of repair and the vessel is in good overall condition.

Discovery: See above 
References: Newton 1852; Smith 1914-15, 87, 93; Curle 1931-2, 310, 313-314, Fig. 21; Hawkes 1951, 183; Piggott 1952-3, 40 No. B2, Fig. 7; Spratling 1971, 112; Macgregor 1976, 151, 170, No. 302; Loughran 1989 No. S5.

\section{Blackburn Mill III, Berwickshire, Scotland}

Location: National Museum of Scotland, Edinburgh (DW148a)

Dimensions: External Diameter of Handle: c.115mm

Type: Unknown

Description: Cauldron fragment. Part of the rim and body of the cauldron survive, as well as the remains of a copper-alloy clamp or clip which is folded over the top of the rim. The iron rim is square in cross-section.

Discovery: See above

References: Piggott 1952-3, 42, No. B14; Loughran 1989 No. S1.

Bog of Allen, Co. Kilkenny, Ireland

Location: National Museum of Ireland, Dublin (NMI R.S.A.I. 281)

Dimensions: Diameter at mouth: 620mm; Height: $475 \mathrm{~mm}$

Type: Projecting-bellied (Group I)

Description: Projecting-bellied copper-alloy cauldron made from three sheets. A hemispherical bowl with shoulder carination is riveted to an upper tier which comprises two rectangular sheets joined by two vertical columns of rivets. The overlap of the sheets is not great hence the two columns of rivets are quite close to one another. Along the top of the upper tier are 5 rivet holes, perhaps remnants of the rim attachment. There are 20+ internal patches, most of which (17) are repairs to the base.

Discovery: Found $2.1 \mathrm{~m}$ below the surface of the peat during turf cutting in 1853

References: McEvoy 1854-5, 131-132; Armstrong 1923, 25, Fig. 13. 1; Macgregor 1976, 17; Raftery 1980, 59, Fig. 8; Raftery 1983, 210, No. 559, Fig. 170; Raftery 1984, 234, 316; Loughran 1989 No. 12.

\section{*Cadbury Castle, Somerset, England}

Location: Somerset County Museum, Taunton

Dimensions: Vessel 1: Diameter at mouth: c. $360 \mathrm{~mm}$. Vessel 2: Diameter at mouth: c. 500mm

Type: Globular?

Description: Four iron rim fragments, at least six iron band fragments and six iron ring handles with attachments. Only two of the handles look to be a pair, meaning that the handles come from up to five different cauldrons. One handle is attached 
by means of a staple and a diamond-shaped washer which still survive. The rim fragments are represented by two different sizes allowing the reconstruction of approximate diameters. Some of the band fragments still have copper-alloy rivets attached where the bowl of the cauldron or a further band was attached.

Discovery: From the hillfort known as Cadbury Castle

References: Barrett el al. 2000, 227, Fig. 134.

\section{Carlingwark Loch, Kirkcudbright, Scotland}

Location: National Museum of Scotland, Edinburgh (DW1)

Dimensions: Maximum Diameter: 680mm; Diameter at mouth: 640mm; Height: 458mm

Type: Projecting-bellied (Group I)

Description: Projecting-bellied copper-alloy cauldron made from three sheets. A hemispherical bowl with shoulder carination is riveted to an upper band which comprises two rectangular sheets joined by three vertical columns of rivets. These form a decorative feature. The handles are missing and there are oblong-shaped gaps in the central upper portions of the overlaps between the two sheets which is probably where they were affixed. There is an area of oxidisation in one of the positions where the handle was affixed implying that the missing parts of the cauldron - handle and rim - were iron. There is extensive evidence for repair. Close to one handle and the rim there is a roughly semi-circular patch. There are four large and three small patches visible on the inside of the base. Along the sides of the cauldron there are also numerous repairs, including between 20-30 so-called 'paper-clip' repairs.

Two sheet fragments, both with evidence of repair and patching, represent the remains of one or more cauldrons probably of the same type (Piggott 1952-3, 34, Nos. C17 \& C18).

Discovery: Discovered in the loch by two fishermen in 1866 forming part of a large collection of local and Roman metalwork. The objects were contained within the cauldron.

References: Anon. 1866-8, 7-9, PI. I; Smith 1914-15, 87, 93-4; Curle 1931-2, 310-313, Fig. 18; Hawkes 1951, 183, Fig 47a; Piggott 1952-3, 28, 31 Fig. 7, C1; Spratling 1971, 111; Macgregor 1976, 170, Fig. 309; Loughran 1989, No. S2.

\section{Chiseldon, Wiltshire, England}

Location: The British Museum, London (P\&E 2007,8034.ff)

Dimensions: Vessel SF5. Maximum Diameter: $448 \mathrm{~mm}$

Vessel SF7. Maximum Diameter: $420 \mathrm{~mm}$; Height $>223 \mathrm{~mm}$

Vessel SF8. Maximum Diameter: $500 \mathrm{~mm}$; Height $>340 \mathrm{~mm}$

Vessel SF9. Maximum Diameter: 450mm

Vessel SF11. Maximum Diameter: c.540mm 


\begin{abstract}
Vessel SF10. Maximum Diameter: 480mm
Vessel SF13. Maximum Diameter: $450 \mathrm{~mm}$

Vessel SF82. Unable to determine dimensions from CT scan

Vessel SF87. Maximum Diameter: 560mm; Height c. $298 \mathrm{~mm}$

Vessel SF105. Maximum Diameter: 520mm; Height $>298 \mathrm{~mm}$

Vessel SF123. Maximum Diameter 550mm; Height c.310mm

Vessel SF149. Maximum Diameter 450mm; Height 290mm

Vessel SF150. Maximum Diameter 500mm

Vessel SF153. Maximum Diameter 310mm; Height 230mm

Vessel SF154. Maximum Diameter 440mm

Vessel UK1. Maximum Diameter 340mm; Height 246mm

Vessel UK2. Unable to determine dimensions from CT scan
\end{abstract}

Type: Globular (Group II)

Description: 17 complete cauldrons as well as numerous fragments. The cauldrons are yet to be published but all are of Group II form with copper-alloy bowls and bands of copper-alloy and/or iron. Rims are of iron with three different types identified. Handles are iron and ring-shaped. Where handle attachments survive, they comprise of iron staples with three bands. Many of the cauldrons show evidence of repair, some with fancily shaped patches. At least three of the cauldrons are decorated.

Discovery: Discovered by metal detector user in 2004. Excavated in 2005. The cauldrons were arranged in a large pit $2 \mathrm{~m}$ in diameter alongside two cow skulls. Evidence from the immediate vicinity indicates that the pit is located within a small settlement.

References: Joy \& Baldwin (forthcoming)

Radiocarbon date: From associated cow bone:

\begin{tabular}{c|c|c} 
Laboratory Code & Object Number & Radiocarbon Age (BP) \\
\hline SUERC-45221 & $55 \mathrm{a}$ & $2197 \pm 22$ \\
\hline SUERC-45222 & $55 \mathrm{~b}$ & $2184 \pm 22$ \\
\hline SUERC-45223 & $117 \mathrm{a}$ & $2184 \pm 23$ \\
\hline SUERC-45224 & $117 \mathrm{~b}$ & $2223 \pm 25$
\end{tabular}

Multiple dates subjected to Bayesian analysis (see Barclay \& Grant in Joy \& Baldwin forthcoming): 
See Barclay and Grant (in Joy \& Baldwin forthcoming) for full analysis of dates.

\section{Cloonfinlough, Co. Roscommon, Ireland}

Location: National Museum of Ireland, Dublin (NMI W22)

Dimensions: Diameter at mouth: $430 \mathrm{~mm}$; Surviving height: $235 \mathrm{~mm}$

Type: Globular (Group II?)

Description: The upper half of a copper-alloy globular-shaped bowl. Rivet holes indicate the position of the missing handles. These form a diamond. One patch is present. This is secured by six 'paper-clip' repairs. Loughran (1989: 88) suggests that this method of attachment for a repair could be an indication that the cauldron is later in date. More likely, these remains are Iron Age and have possibly been later re-worked. The top of the bowl ends at the top in a vertical lip $20 \mathrm{~mm}$ in height. The bottom section is folded over making it difficult to tell how the bowl was originally attached.

Discovery: Unknown

References: Raftery 1980, 60; Loughran 1989 No. I11.

\section{Crummackdale, Austwick, Yorkshire, England}

Location: British Museum, London (P\&E 1954.0701.1)

Dimensions: Diameter at mouth: 450-560mm; Height: 356mm

Type: Projecting-bellied (Group I)

Description: Projecting-bellied copper-alloy cauldron made from two sheets. A hemispherical bowl with shoulder carination is riveted to an upper band which comprises of one long strip which overlaps itself diagonally and is joined by rivets. There is also complex patching around the upper band. Paired rivet holes on opposite sides of the cauldron indicate the position of the now missing handles. Staining near the top of the upper band indicates that the missing rim was made of iron. There are numerous repairs. At the base there are six large patches and three small. There are three 'paper-clip' repairs at the neck.

Discovery: Found before 1937 when cutting drainage channels in a dried-up tarn $1 \frac{1}{2}$ miles north of Austwick, at a depth of $40 \mathrm{cms}$.

References: Mattison \& Palmer 1937, 164; Hawkes 1951, 185, 180 with Fig. 47 f; Macgregor 1976, 170, Fig. 310; Loughran 1989 No. E2.

*Dernaveagh Bog, Co. Antrim, Ireland

Location: Ulster Museum, Belfast (279 1925) 
Dimensions: Diameter at mouth: 420mm; Height: $309 \mathrm{~mm}$

Type: Globular (Group III)

Description: Copper-alloy globular bowl. It has a vertical neck with no rivet holes which is approximately $20 \mathrm{~mm}$ deep. Two sets of rivet holes below the neck, opposite one another indicate the position of the missing handles. The vessel is dented and torn. It is much repaired with patches secured by 'paper-clip' rivets.

Discovery: Unknown

References: Anon 1924, No. 679; Macgregor 1976, 170, Fig. 300; Loughran 1989, No. S3.

\section{*Elvanfoot, Lanarkshire, Scotland}

Location: Hunterian Museum, Glasgow (B 1959 3224)

Dimensions: Diameter at mouth: $420 \mathrm{~mm}$; Height: $261 \mathrm{~mm}$

Type: Globular (Group IV)

Description: Globular copper-alloy bowl with a short vertical neck. The neck is perforated by nine holes punched from the inside. There is a single 'paper-clip' repair just below the neck. The iron? handles and rim are missing, otherwise the vessel is in excellent condition. Close-set punch marks are visible across the surface of the cauldron. These have been punched out from the inside and form a spiral pattern, worked up from the base upwards. Macgregor $(1976$, no. 303$)$ suggests the vessel has been sunk using a hollow mould.

Discovery: Found in peat, circumstances unknown

References: Burns 1969, 29 ff, 32 Fig. 1; Spratling 1971, 111 f.; Macgregor 1976, 151, 170, No. 303; Loughran 1989, No. S6

\section{Ewartly Shank, Alnhammoor, Northumberland, England}

Location: Great North Museum, Newcastle (1956 227A)

Dimensions: Diameter at mouth: 420mm; Height: $240 \mathrm{~mm}$

Type: Globular (Group IV)

Description: Globular copper-alloy bowl with a short $(14 \mathrm{~mm})$ vertical neck. The neck is perforated by 10 rivet holes. The iron? rim and handles are now missing. At the bottom of the bowl, close-set oval shaped punch marks are visible. These are quite deep and are roughly $10 \mathrm{~mm} \times 5 \mathrm{~mm}$ in size. They are marked out in a spiral motif but it is unclear how far up the bowl they extend as they peter out. Overall the bowl is in very good condition except for some damage in the upper part. Discovery: Circumstances unknown.

References: Spratling 1971, 112; Spratling 1972, 238; Macgregor 1976, 170, No. 304; Loughran 1989, No. E8; Hunter 1997, 125. 


\section{Glenfield, Leicestershire, England}

Location: The British Museum, London (P\&E 2010.8017.1-2)

Dimensions: $\quad$ Vessel 1: Maximum diameter: $480 \mathrm{~mm}$; Height: $180 \mathrm{~mm}$

Vessel 2: Maximum diameter: 620mm; Height: unknown

Type: Globular (Group II)

Description: At least two vessels of similar form but different sizes. Both are hemispherical in shape and comprise a copperalloy bowl, a thick iron band and an iron rim with two iron ring-shaped handles. Although they vary in size, both vessels are sufficiently large to be categorised as cauldrons.

Discovery: Recovered in 2009 during an archaeological evaluation undertaken by Cotswold Archaeology Ltd. The objects were found side by side and remain in their lifted state with the highly fragmentary remains supported in blocks of soil. The cauldrons were donated to the British Museum by the landowners, Lynwood Farm Estates. The findspot is probably the site of a settlement.

References: Unpublished Treasure Report (2009 T712).

\section{Gullane, East Lothian, Scotland}

Location: National Museum of Scotland, Edinburgh (DU14)

Dimensions: Maximum diameter: $310 \mathrm{~mm}$

Type: Globular (Group IV)

Description: Two large copper-alloy bowl fragments. Although they are not in brilliant condition, the two surviving pieces make it possible to re-construct the full diameter of the vessel. A narrow vertical neck approximately $20 \mathrm{~mm}$ high runs along the top of the bowl. This is perforated by a number of large, circular rivet holes. The base section also has a number of rivet holes so the cauldron originally had a circular base attached to the main body by rivets. As this no longer survives it is impossible to establish if this was part of the original manufacture or if it was a repair. Both handle attachments are visible. These comprise an internal plate for strengthening, secured to the main body of the cauldron by four rivets. The plate sits inside the cauldron with the top overhanging the neck on the outside following its contours. A little to one side of where one handle was positioned is another hole and a possible repair. It is possible that this handle was re-positioned at some point in the past. It is impossible to ascertain if this occurred for both handles as the opposite section no longer survives.

Discovery: Discovered on the beach by metal detector user

References: DES 1992, 50; Hunter 1997, 125. 
Inveresk, East Lothian, Scotland

Location: National Museum of Edinburgh, Scotland (FR 756)

Dimensions: Dimensions of largest fragment: 220x360mm

Type: Projecting-bellied (Group I)

Description: Seven large and seven smaller sections forming the substantial remains of a cauldron. Two other fragments may form the base and part of the body of a further two cauldrons.

Enough of the first cauldron survives to make it possible to re-construct its profile. It is projecting-bellied, comprising a hemispherical bowl with shoulder carination riveted to a cylindrical upper band. The very bottom of the bowl comprises a small circular disc of sheet metal, riveted to the main body by $40-50$ rivets and an additional 3 strengthening bars. This central bottom section is approximately $120 \mathrm{~mm}$ in diameter. The strengthening bars indicate that this is probably a repair. Areas of 'rust-like' corrosion can be seen on two of the sections. These looked initially to be possible remains of an iron rim but on closer inspection it is more likely to be some other kind of corrosion product.

There is a further large section which belongs to a separate cauldron. The metal is thicker and has a different patina. The fragment that remains is also constructed in a different way from the other fragments. It is made up of two bands of metal riveted together, one overlapping the other.

A third fragment comprises a cauldron bowl. Since we already have the bowl of the cauldron described above it must be from another vessel but it could not be ascertained whether it belongs to the second fragment or a separate, third vessel. Although, like the second cauldron, the metal is thicker than the first vessel, the patina resembles that of the first vessel. The most interesting feature of this fragment is the central rivet hole which has not been plugged. This is presumably a result of spinning or lathe turning during manufacture.

Discovery: Unknown

References: Unpublished

*Ipswich, Suffolk, England

Location: Ipswich Museum, Ipswich (1920-90-3)

Dimensions: Dimensions of fragment: c.155x100mm

Type: Globular (Group II?)

Description: Collection of fragments including three strips of copper-alloy of double thickness with rivets in situ and section of a copper-alloy bowl.

Discovery: Found in the 1920's during street development in Berners Street, Ipswich.

References: Clarke 1939, 73; Loughran 1989, No. E9. 


\section{Letchworth, Hertfordshire, England}

Location: Letchworth Museum

Dimensions: Maximum Diameter: 513mm; Diameter at mouth: 508mm; External Diameter of Handle: $105 \mathrm{~mm}$

Type: Globular (Group II)

Description: Iron rim, upper band and handles of a cauldron. The rim is rounded in cross-section. The handles are round in cross-section. Each is secured to the upper band by one large staple, held in place by a single rivet. The staple has three ridges. Two round 'stoppers' are located below each handle.

Discovery: Discovered during excavation of a settlement. The cauldron fragment was found in a ditch alongside pottery sherds dating to the first and second centuries BC.

References: Moss-Eccardt 1965, 173 ff., PI. 45; Spratling 1971, 112; Spratling 1972, 236-237; Macgregor 1976, 170; MossEccardt 1988, 88-90; Loughran 1989, No. E10.

\section{Llyn Cerrig Bach I, Anglesey, Wales}

Location: National Museum, Cardiff (44.32.76i)

Dimensions: Width: 240mm; Height: 215mm; Weight: 85.9g

Type: Globular?

Description: Copper-alloy sheet fragment. Some modern damage caused by folding after discovery. There is evidence that the fragment was cut during antiquity. Three copper-alloy patches are fixed to the upper section of the inside surface close to the rim by rivets. Two remain in situ. One is incomplete attached by a single rivet. The other is elaborately made. It tapers has a waisted form and is secured by three rivets. It is difficult to be certain but these patches were probably put in place at the time of manufacture rather than showing evidence for ancient repair. The external face is blackened, probably oxidization caused by usage. Traces of iron corrosion remain, indicating that the upper band was probably made of iron. No visible hammer marks.

Discovery: Found during construction work at RAF Valley, Anglesey in 1942. Part of a total of 170 iron, copper-alloy and wood artefacts and animal bones originally deposited in a small lake.

References: Fox 1946, 42 f., PI. 38, Nos. 76 \& 77; Savory 1976, Fig. 29; Macgregor 1976, 170; Loughran 1989, No. W1-3; Macdonald 2007, 88-97, 225-226, PI. 1a, Figs. 17-19, no. 24.

Metal Analysis: see Macdonald 2007, Table 18.

Llyn Cerrig Bach II, Anglesey, Wales

Location: National Museum, Cardiff (44.32.76ii) 
Dimensions: Width: 280mm; Height: 210mm; Weight: $62.6 \mathrm{~g}$

Type: Globular?

Description: Copper-alloy sheet fragment. Some modern damage caused by folding after discovery. Part of the edge of the fragment was deliberately cut in antiquity. In one corner is a rivet fixing two square washers still in situ. The external face is blackened, probably oxidization caused by usage. Traces of iron corrosion remain, indicating the upper band was probably made of iron. Rivet holes are also visible at this juncture. In poor overall condition and visibly worse than the other two fragments from this site.

Discovery: See above.

References: Fox 1946, 42 f., Pl. 38 Nos. 76 \& 77; Savory 1976, Fig. 29; Macgregor 1976, 170; Loughran 1989, No. W1-3; Macdonald 2007, 88-97, 226, PI. 1a, Figs. 17-19, No. 25.

Metal Analysis: see Macdonald 2007, Table 18.

Llyn Cerrig Bach III, Anglesey, Wales

Location: National Museum, Cardiff (44.32.77)

Dimensions: Width: 145mm; Height: 275mm; Weight: $67.5 \mathrm{~g}$

Type: Globular?

Description: Copper-alloy sheet fragment. The fragment is creased. It is uncertain whether this is ancient or associated with discovery. There are four patches on the internal surface. Corrosion associated with a fifth patch can also be seen. The patches are four-sided and circular in form and are fixed with rivets. One patch is superimposed on another. Part of the edge of the fragment was deliberately cut in antiquity.

Discovery: See above

References: Fox 1946, 42 f., PI. 38 Nos. 76 \& 77; Savory 1976, Fig. 29; Macgregor 1976, 170; Loughran 1989, No. W1-3; Macdonald 2007, 88-97, 226-227, Pl. 1a, Figs. 17-19, No. 26.

Metal Analysis: see Macdonald 2007, Table 18.

Loch Gamhna, Inverness, Scotland

Location: National Museum of Scotland, Edinburgh (DU13)

Dimensions: Maximum diameter: $470 \mathrm{~mm}$

Type: Projecting-bellied (Group I)

Description: Copper-alloy cauldron in very fragmentary condition. The largest pieces comprise a circular bowl section and an upper band formed from one long sheet of copper-alloy. The surviving bowl is much distorted. The join between bowl and band is secured by rivets. It is not possible to discern where the two ends of the upper band join. This was presumably 
in the area with most damage where a small section is now missing. It is difficult to make out where the handles were originally attached. There are two possible locations. In the area where a large portion of the upper band is now missing, there is reinforcement of the join. On the opposite side there is a reinforcement bar. This is rectangular in form and is secured by rivets. The alternative position of handle attachment is a large rectangular-shaped gap but there is no corresponding area on the other side, except for two holes.

Present in the fragments is a section similar to the area where the handles were fixed to the Carlingwark cauldron, with decorative rows of rivets. Building on this information, a similar construction for the Loch Gamhna cauldron can be suggested. The upper band is between $10-20 \mathrm{~mm}$ in width and is riveted to the inside of the bowl. In some places there are two rows of rivets, in others just one. Not enough of this band survives to reconstruct the height of the cauldron. The question of whether the cauldron had an iron rim or not is now impossible to ascertain, in parts the copper-alloy curves over the interior band, it is possible if there was an iron rim that it was located inside this fold. One fragment has a repair where one patch superimposes another.

Discovery: Discovered $1^{\text {st }}$ May 1964 in about $50 \mathrm{cms}$ of water, $2.5 \mathrm{~m}$ from the shore of the loch References: Forsyth 1964; Hunter 1997, 126.

\section{*Loughan Ford, Ireland}

Location: Ulster Museum, Belfast

Dimensions: Unknown

Type: Globular?

Description: Four large fragments of copper-alloy sheet.

Discovery: Circumstances unknown

References: Gerloff 2010, 377.

\section{Lound Run, Suffolk, England}

Location: British Museum, London (P\&E 1898.0516.1)

Dimensions: Maximum Diameter: 330mm; Height: 160-165mm

Type: Globular (Group II)

Description: Hemispherical copper-alloy bowl fragment. Iron rivets in situ at the edge of the fragment indicating that the upper band was probably iron. Three patches (two large rectangular patches and one additional repair near the upper edge) are visible in the upper and lower parts of the bowl and there are two 'paper-clip' repairs.

Discovery: Found in 1898 while excavating peat from a silted-up channel called Lound Run, 1.5-1.8m below the surface. References: Clarke 1939, 73, PI. XX. 
Manorbier, Pembrokeshire, Wales

Location: National Museum, Cardiff (2005.28H)

Type: Globular (Group III?)

Description: Numerous fragments of copper-alloy as well as well-preserved iron rim fragments. The copper-alloy is very thin and in poor condition. There are a number of pieces with patches secured by rounded and square rivets indicating the cauldron may have been much repaired. Similarly much of the iron is highly corroded and the finds have not been fully cleaned. The single section of rim that has been cleaned is in very good condition. It comprises a thin folded-over strip with a flat top, creating a T-shaped profile. A small section of copper-alloy is still in situ indicating that the rim was fitted onto the bowl/band by means of a slot in the lower half of the rim. There is a blackened oxidized layer on the outside surface of some of the copper-alloy.

The cauldron is attributed to Group III based on an absence of rivets along the surviving section of rim and band but the area of handle attachment does not survive, meaning that the attribution cannot be entirely certain. Discovery: Discovered by a metal-detector user in 2005. Part of a group containing five complete and at least three other fragmentary objects. These include a trulleus with openwork decoration, two dippers and two strainers. The cauldron remains comprise one of the fragments. In addition, there are two flat-bottomed dishes.

References: Chapman (in Redknap 2011: 92).

New Mains, Whitekirk, East Lothian

Location: National Museum of Scotland, Edinburgh (unregistered)

Dimensions: $\quad$ Fragment 1 (sticky labels read "2" and "A"): Width: $165 \mathrm{~mm}$; Height: $118 \mathrm{~m}$

Fragment 2 (probably joins fragment 1): Width: 113mm; Height: $35 \mathrm{~mm}$

Fragment 3: Width 70mm; Height: $54 \mathrm{~mm}$

Fragment 4: Width: 116mm; Height: 55m

Type: Globular?

Description: "Four fragments of sheet copper alloy, plausibly from the one vessel. Two of them join (tentatively) to form the incomplete convex shouldered profile of a vessel, with rim and base lost. Creases on the larger fragment suggest it was bent when found but has been reshaped. The restoration seems plausible, and gives a maximum diameter estimated at $260 \mathrm{~mm}$ at the shoulder. The form is likely to be globular. Shallow circumferential grooves on the interior survive from the hammering process. The upper edge of the larger fragment has traces of a repair patch on the outer surface; the patch is lost, but the two rolled-sheet rivets which held it are in place, and retain fragments of the patch. This may correlate with a surviving patch fragment on one of the other fragments, and may have been ripped when the cauldron was damaged; or 
they may represent separate patching episodes. It seems unlikely that the vessel held the hoard, as there is evidence that it was incomplete when buried, not just damaged. The smaller joining fragment (no 2 ) has a patch of small round indents (D $3.5 \mathrm{~mm}$ ) in one area, suggesting deliberate damage. More curious is the straight lower edge, now a little worn (inhibiting certain identification), but the straightness suggests it was deliberately cut. It is cut neatly around the circumference, so must have taken place when the vessel was whole, not flattened" (Fraser Hunter pers.comm 2013).

Discovery: Found in the late 1960s/early 1970s, in fieldwalking after the discovery of a Roman Iron Age hoard (Macgregor 1976, Nos. 14, 206, 220) comprising a bridle bit ring, beaded torc, spiral armlet, and fragmentary Roman patera. The vessel is likely to be related to the hoard.

References: Macgregor 1976

\section{Santon, Norfolk, England}

Location: Museum of Archaeology and Anthropology, Cambridge (MAA 1987-06-09)

Dimensions: Diameter at mouth: 420mm; Height: 300mm; External Diameter of Handle: $90 \mathrm{~mm}$

Type: Projecting-bellied (Group I)

Description: Comprising two substantial pieces of copper-alloy as well as an iron rim and two iron ring handles. It is in fragmentary condition, particularly at the base, and has been restored. A hemispherical copper-alloy bowl with shoulder carination is riveted to an upper band which comprises one long strip which overlaps itself by $50 \mathrm{~mm}$ and is joined by two near vertical columns of nine rivets. The iron rim is diamond-shaped in cross-section and is attached to the top of the upper band by copper-alloy rectangular shaped clips which are $60 \mathrm{~mm} \times 25 \mathrm{~mm}$ in size and secured to the upper band by three rivets. Three of the original clips survive. The handles are riveted to the upper band by T-shaped iron staples (110 $\mathrm{x}$ $25 \mathrm{~mm}$ ). The very bottom of the bowl has been replaced with a circular disc $250 \mathrm{~mm}$ in diameter fitted to the outside of the bowl. This is of different thickness from the rest of the bowl indicating that it is an ancient repair. There are a number of other repairs on the body but owing to the condition of the object, it is difficult to quantify them. A number of the repairs act to reinforce the upper band at the position of handle attachment. A further repair located at the point of handle attachment is multi-phase with two patches superimposing a larger primary repair patch.

Discovery: Found in 1897 by a labourer who initially reported the findspot as his garden in Santon Downham. The findspot was later established as being in the parish of Santon. The findspot is probably on the site of a settlement. The find comprises over 100 local and Roman objects deposited within the cauldron. References: Smith 1909, 146-8, PI. XV.1; Smith 1914-15, 87-9; Fox 1923, 104; Curle 1931-2, 310-311; Clarke 1939, 71-72; Hawkes 1951, 182; Spratling 1972, 235-236, No. 429; Macgregor 1976, 170; Loughran 1989 No. E5. 


\section{Sedgeford, Norfolk, England}

Location: Norwich Castle Museum, Norwich (2012.110)

Dimensions: Diameter at mouth: $350 \mathrm{~mm}$; Surviving Height: $120 \mathrm{~mm}$

Type: Projecting-bellied (Group I)

Description: Projecting-bellied cauldron in very bad condition. It comprises the substantial portion of a copper-alloy bowl and parts of a copper-alloy band. The join between the bowl and band are secured by small circular rivets spaced approximately $7 \mathrm{~mm}$ apart. Some fragments of iron also survive. One piece is identifiable as an iron handle attachment which is secured to the point of overlap of the upper band by two substantial rivets.

Discovery: Discovered in 2006 by Mr Roger Greaves on the surface of a field next to a hole (NGR TF 7108835727) while out walking his dog. It was probably uncovered by nighthawks who were disturbed by the local gamekeeper.

References: Unpublished

\section{*Shepperton, Surrey, England}

Location: Chertsey Museum, Chertsey

Dimensions: Width: 320mm; Height: 150mm

Type: Globular (Group II)

Description: Hemispherical shaped copper-alloy bowl. Rivets remain at the edge as do remains of a copper-alloy upper band. Numerous repairs are present.

Discovery: Discovered in 1987 during gravel extraction in a now extinct channel of the River Thames References: Gerloff 2010, 376.

\section{Spetisbury Rings, Dorset, England}

Location: British Museum, London (P\&E 1862.0627.1)

Dimensions: Maximum diameter: $280 \mathrm{~mm}$; Diameter at mouth: 240mm; Height: 195mm

Type: Globular (Group II)

Description: Copper-alloy hemispherical bowl riveted to an upper band formed of a long single band. The vessel has an iron rim which is diamond shaped in cross-section. Originally the two sections were joined by 32 rivets, one is now missing. The rivets are relatively large ( $6 \mathrm{~mm}$ in diameter) and dome-headed. They are spaced approximately $15 \mathrm{~mm}$ apart. The upper band overlaps by c. $25 \mathrm{~mm}$ and was the position of one of the handle attachments. The handle attachments themselves are missing, as are the handles and both were attached to the upper band by two vertically spaced rivets which are $40 \mathrm{~mm}$ apart. The cauldron is heavily corroded making it difficult to identify ancient repairs. There is one repair patch located on 
the inside of the vessel near the seam. It is nicely shaped and could possibly have been added at the time of manufacture rather than being a later repair.

Discovery: Found during railway construction in 1857 in a large pit alongside other artefacts, including weapons, pottery, currency bars and buckets, as well as human remains.

References: Smith 1925, 134 f., Fig. 147; Gresham 1939, 120-122, Fig. 5; Spratling 1972, 229, 579, No. 404, Fig. 184;

Macgregor 1976, 170; Loughran 1989, No. E13.

Urlingford, Co. Kilkenny, Ireland

Location: National Museum of Ireland, Dublin (NMI R.S.A.I. 281)

Dimensions: Diameter at mouth: 620mm; Height: $475 \mathrm{~mm}$

Type: Projecting-bellied (Group I)

Description: Projecting-bellied cauldron with copper-alloy bowl and band. The bowl is large with pronounced shoulder carination. The upper band comprises two sheets held together by two rows of evenly spaced, small, circular rivets. The two sheets overlap by $30-35 \mathrm{~mm}$. The upper band is riveted to the outside of the bowl using small circular rivets spaced roughly $5 \mathrm{~mm}$ apart. Two possible handle locations are visible. Diametrically opposed to each other are two sets of two large circular holes (roughly $10 \mathrm{~mm}$ in diameter). These are aligned horizontally and are spaced $180 \mathrm{~mm}$ apart. They are located in the two other quadrants from where the bands overlap, $40 \mathrm{~mm}$ below the top of the cauldron. The alternative, and more likely, location for the handles is at the point where the upper bands overlap. At both points of overlap, and diametrically opposed to one another, are two large circular holes aligned vertically and spaced 150mm apart. Patches are also visible on the inside of the cauldron at both of these locations of overlap. The cauldron has been extensively repaired with square, D, rhomboid and rectangular shaped patches riveted to the inside of the vessel. There are 6 patches on the upper band and up to 17 patches on the bowl, located at the shoulder. A further paper-clip repair and one washer are also present.

Discovery: Found in the Bog of Allen during turf cutting, 7 feet below the surface on $23^{\text {rd }}$ May 1853 (McEvoy 1854-5, 131). References: McEvoy 1854-5, 131-132; Armstrong 1923, 25, Fig. 13.2; Raftery 1980, 59; Raftery 1983, No. 559, Fig. 170; Loughran 1989, No. 12, 75-77.

\section{Walthamstow I, Essex, England}

Location: British Museum, London (P\&E OA.10953)

Dimensions: Maximum diameter: 370-400mm; Height: 195mm

Type: Globular (Group II) 
Description: Copper-alloy hemispherical bowl. A series of rivets and iron fragments in situ on the outer edge indicate that the upper band was iron. There are two patches on the inside surface, one sub-rectangular in shape. A hole in the centre has been plugged by a rivet.

Discovery: From the river Thames at Walthamstow. Circumstances unknown.

References: Smith 1906-07, 329-30; Smith 1914-15, 87-88; Hatley 1933, 19-20, 29, Fig. 14; Spratling 1971, 112; Spratling 1972, 236, No. 430; Macgregor 1976, 170; Loughran 1989, No. E14.

\section{Walthamstow II, Essex, England}

Location: British Museum, London (P\&E OA.10954)

Dimensions: Maximum diameter: 510mm; Height: $270 \mathrm{~mm}$

Type: Globular (Group II)

Description: Copper-alloy hemispherical bowl. Originally this vessel would have comprised an upper-band but this is now missing. The vessel has been heavily repaired. The base has been replaced with a disc-shaped patch and there are also a number of other ancient patches.

Discovery: From the River Thames at Walthamstow. Circumstances unknown.

References: Smith 1905-07, 329; Macgregor 1976, 170; Loughran 1989, No. E15.

\section{Welshpool, Powys, Wales}

Location: National Museum, Cardiff (60.234/5) (on loan from Powys County Council)

Dimensions: Diameter at mouth: 394mm*; Height: 250mm*

Type: Globular (Group III?)

Description: Comprising three large pieces and three fragments of copper-alloy sheet. Two of the larger pieces have iron rims attached to the sheet. The rim is approximately $20 \mathrm{~mm}$ wide and sits roughly vertically above the copper-alloy section which has a pronounced shoulder. In cross-section the rim is lipped at the top. The join between rim and bowl is made by means of a narrow groove in the rim approximately $10 \mathrm{~mm}$ wide. The top of the bowl slots inside the groove. The third large piece is a substantial piece of the bowl and is hemispherical in shape. The upper section is missing. Based on surviving sections joining the rim, it is thought that the overall shape was globular rather than hemispherical. There is a small central hole in the base which has been plugged with copper-alloy. No evidence for handle attachment or repairs survives.

The cauldron is attributed to Group III based on an absence of rivets along the surviving section where the rim was originally attached but the area of handle attachment does not survive, meaning that the attribution cannot be entirely certain. 
Discovery: Discovered in 1960 by workmen laying a drain. Thought to be the remains of a cremation burial. The cauldron contained three Roman paterae and a ewer. Also present were a bucket with an ox-head escutcheon, two iron firedogs, a glass jar, the stamped base of a glass mould-blown bottle and a pottery vessel. A sample of wood from the bucket was sampled and C14 dated giving a result of 1-140 cal. AD (92.9\%). Gwilt (forthcoming 2014) dates the grave-goods to AD $65-$ 150.

References: Boon 1961, 13 ff.; Eggers 1966, 103, No. 16; Loughran 1989, No. W 3.

Radiocarbon date: From a bucket stave of Yew - OxA-17440

$1915 \pm 30 \mathrm{BP}$

1-140 cal. AD (92.9\%)

$150-170$ cal. AD (1.3\%)

190-210 cal. AD (1.2\%)

Date published in Garrow et al. (2009, 119), discussed by Gwilt (forthcoming 2014).

Whitemills Moss, Dumfriesshire, Scotland

Location: National Museum of Scotland, Edinburgh (DU6)

Dimensions: Maximum diameter: $360 \mathrm{~mm}$; Diameter at mouth: $340 \mathrm{~mm}$; Height: $210 \mathrm{~mm}$

Type: Globular (Group IV)

Description: Copper-alloy globular-shaped bowl comprising a single piece hammered into shape. In very good condition. At the top is a narrow, vertical band approximately $15 \mathrm{~mm}$ high. This has nine equally spaced rivet holes running around it. The rivet holes are quite large and circular. There is no evidence for handle attachment so this must have also occurred on the missing rim. There are very few imperfections visible. The only visible repair occurs approximately $40 \mathrm{~mm}$ from the base where there is a large 'paper clip' repair with two bands of metal visible on the outside.

Discovery: Found before 1889. Circumstances unknown.

References: Anon. 1889-90, 16; Macgregor 1976, 151, 170, No. 307; Loughran 1989, No. S6.

\section{Woodburn, Dalkeith, Midlothian, Scotland}

Location: National Museum of Scotland, Edinburgh (DU12)

Dimensions: Width: 140mm; Height: $120 \mathrm{~mm}$

Type: Unknown

Description: Comprising four patches of sheet copper-alloy riveted together in a complex pattern.

Discovery: Circumstances unknown

References: Unpublished 


\section{Wormegay, Norfolk, England}

Location: Norwich Castle Museum, Norwich (1954.67)

Dimensions: Diameter at mouth: $335 \mathrm{~mm}$; Height: $270 \mathrm{~mm}$

Type: Projecting-bellied (Group I)

Description: A hemispherical bowl with distinct shoulder carination is riveted to an upper band which comprises one long strip which overlaps itself and is secured by two inward slanting columns of rivets. The overlap varies between $70 \mathrm{~mm}$ at the top and $90 \mathrm{~mm}$ at the bottom. The band is $100 \mathrm{~mm}$ wide and is riveted to the outside of the bowl. The rivets securing this join are small and spaced 5-7mm apart. The iron rim and handles are missing. Rivet holes at the top of the band indicate that the rim was originally attached using clips. The handles were originally positioned at the overlap of the upper band and diametrically opposite. The remains of the handle attachment comprise three rivet holes arranged at the points of an equilateral triangle spaced $50 \mathrm{~mm}$ apart. There is no evidence of repair. The cauldron is now in a fragmentary state and sits in a specially constructed cradle.

Discovery: Found near Blackburgh Priory during ploughing.

References: Macgregor 1976, 170; Loughran 1989, No. E5.

Ynys-Gwrtheyrn, Llanenddwyn, Gwynedd, Wales

Location: National Museum, Cardiff (21.24/36e)

Dimensions: Diameter at mouth: $240 \mathrm{~mm}$

Type: Globular

Description: The hemispherical copper-alloy base of a possible small cauldron. There is no evidence of repair.

Discovery: "Five bronze cooking utensils, one containing a hoard of coins (mostly Republican but including two of Augustus (27BC - AD14) and one of Vespasian (AD 69-79). Three of the vessels and two Republican coins (AR) are now in the National Museum of Wales" (Griffiths 1948: 120).

References: Griffiths 1948, 120.

Unprovenanced I, Ireland

Location: National Museum of Ireland, Dublin (NMI 1926: 17)

Dimensions: Fragment $1-340 \mathrm{~mm} \times 230 \mathrm{~mm}$; Fragment $2-250 \mathrm{~mm} \times 260 \mathrm{~mm}$

Type: Globular (Group II) 
Description: Two large sheet copper-alloy fragments. One section is broadly rectangular and probably formed part of an upper band. The second is very crumpled. A rectangular patch is visible and is attached to the outside of this second fragment.

Discovery: Circumstances unknown

References: Raftery 1983, 211, No. 561; Loughran 1989 no. I.7

\section{Unprovenanced II, Ireland}

Location: National Museum of Ireland, Dublin

Dimensions: Diameter at mouth: 630mm; Height: $470 \mathrm{~mm}$

Type: Projecting-bellied (Group I)

Description: Projecting-bellied copper-alloy cauldron made from three sheets. A hemispherical bowl with shoulder carination is riveted to an upper band which comprises two rectangular sheets which overlap by approximately $200 \mathrm{~mm}$. It is at these overlapping areas that the handles were originally attached. Torn rivet holes are all that remains of these attachments. The area of the handle attachments was reinforced in antiquity by copper-alloy patches. Other repairs include three long patches at the shoulder and a large circular disc which replaces the base which is 350mm in diameter. There is a further rectangular patch on the upper band.

Discovery: Circumstances unknown

References: Raftery 1980, 59-60, No. 6, Fig. 9.1; Raftery 1983, 211, No. 560, Fig. 171; Loughran 1989, No. I.3.

\section{*Unprovenanced III, Ireland}

Location: Ulster Museum, Belfast

Dimensions: Diameter at mouth: $380 \mathrm{~mm}$; Height: $309 \mathrm{~mm}$

Type: Globular (Group III)

Description: Globular shaped cauldron comprising a single piece of copper-alloy. Two triangular arrangements of rivet holes diametrically opposed to one another and located on the shoulder of the vessel indicate the position of the handles. A series of repairs are visible close to the rim, a second concentration at the base. These rectangular patches are secured by 'paper-clip' rivets.

Discovery: Circumstances unknown

References: Loughran 1989, No. I.15

APPENDIX C: CAULDRONS PREVIOUSLY LISTED ELSEWHERE BUT PROBABLY LATER IN DATE 


\section{Awhirk, Dumfries \& Galloway, Scotland}

Location: National Museum of Scotland, Edinburgh (DU16)

Dimensions: Maximum diameter: 530-470mm; Height: 275mm

Type: Does not fit typology, possibly later in date

Description: Large copper-alloy bowl. The profile of the vessel is unusual. It is not globular and is less rounded than other examples as it tapers substantially towards the bowl. The vessel is unfinished. There is no evidence for rivet holes at the top which could have been used to secure the missing rim. Neither is there evidence for an indentation seen on other cauldrons where the rim has been fitted over the metal. In the centre of the base there is a small hole. This is unplugged and shows no evidence of having been sealed. Striations going around the metal indicate that it was probably spun or finished on a lathe. The metal is quite thick and is in excellent condition.

Discovery: Found by a ploughman on the farm of Awhirk, in the Rhinns of Galloway, on peaty land, probably formerly a bog/moss.

References: Anderson 1938; Hunter 1997, 124.

\section{Denny, Falkirk, Scotland}

Location: National Museum of Scotland, Edinburgh (DU10)

Dimensions: Maximum diameter: 460mm

Type: Globular? Uncertain date

Description: Circular piece of copper-alloy. A possible cauldron base but it is very flat. The edges are very fragmentary but the metal is bent over in places with some possible rivet holes. Set approximately $40 \mathrm{~mm}$ from the edge are 29 equally spaced holes. One of these is filled with a 'paper-clip' like repair. Not certain to be Iron Age/early Roman.

Discovery: Unknown

References: Unpublished.

\section{Kilmihil, Lack East, Co. Clare, Ireland}

Location: National Museum of Ireland, Dublin (NMI 1943/236)

Dimensions: Diameter at mouth: c. 500mm; Height: c. $450 \mathrm{~mm}$

Type: Doesn't fit the typology. Possibly later in date

Description: Bucket-shaped vessel with a flat bottom. The bottom part comprises rectangular sheets of copper-alloy riveted to one another using 'paper-clip' rivets. The upper half is globular in form and has a short $(16 \mathrm{~mm})$ vertical neck. Loughran (1989: 90) suggests that the topmost portion may be of some antiquity but it was later re-used and added to the bottom 
portion, which is later in date, perhaps medieval. The top section of the cauldron may have originally been globular in shape with a vertical rim and no rivets.

Discovery: Circumstances unknown

References: Raftery 1980, 60; Loughran 1989, No. I 14.

Sessuegarry, Co. Sligo, Ireland

Location: National Museum of Ireland, Dublin (NMI 1942:111)

Dimensions: Maximum Diameter: 550mm; Diameter at mouth: 455mm; Height: $390 \mathrm{~mm}$

Type: Does not fit the typology. Possibly later in date

Description: Loughran (1989: 91) describes this as a composite vessel. The lower half has straight sides and a flat bottom. The upper half is more globular in form. The metal of the lower half is thicker than the metal of the upper half. The joining sections of both halves have been cut in zigzag fashion and the join is secured by 'paper-clip' rivets. A number of patches are attached to the inside surface of the upper half. There are no repairs on the lower half. Loughran suggests that the lower half is not as ancient as the upper portion.

Discovery: Found $60 \mathrm{cms}$ below the surface of a bog. Circumstances unknown

References: Raftery 1980, 60; Raftery 1984, 232; Loughran 1989, No. I14.

Upwell, Norfolk, England

Location: Norwich Castle Museum, Norwich

Dimensions: Maximum diameter: 250mm; Height: $110 \mathrm{~mm}$

Type: Does not fit typology. Possibly later in date

Description: Shallow vessel comprising a copper-alloy bowl and a narrow band. The band comprises one narrow sheet of metal. The ends overlap by $10 \mathrm{~mm}$ and the join is secured by three rivets. The band fits inside the bowl. The attachment between the two is unusual and is secured by folding the top of the bowl into the bottom of the band. The vessel originally had a further band secured above it. The join was secured by rivets. 16 rivet holes are present 10 of which have been filled with paper-clip repairs indicating re-use after the uppermost band was removed in antiquity. One repair patch is present on the band.

Discovery: Discovered in 1976 by mechanical excavator on the Norfolk bank of the Old Croft River at Upwell References: Gregory 1978.

APPENDIX D: CAULDRON FRAGMENTS 


\section{Camerton, Somerset, England}

Description: Possible iron ring handle of a cauldron or bucket

References: Jackson 1990, 66, no. 289, pl. 30

\section{Conderton Camp, Worcestershire, England}

Description: Copper-alloy sheet fragments with rivets and washers in situ.

References: Thomas 2005, 149-150, No. CU12.

Danebury, Hampshire, England

Description: 51 fragments or groups of fragments of sheet copper-alloy, including some large sections which have been folded up (see Cunliffe \& Poole 1991, fig 7.5 (1.113 \& 1.114)) and could be from vessels.

Dating: Elsewhere at the site, from a hoard of iron objects, is a pair of iron cauldron hooks (Cunliffe \& Poole 1991, 353, Fig. 7.21), probably dating to the $2^{\text {nd }}$ century $B C$.

References: Cunliffe \& Poole 1991.

Easton Land, Hampshire, England

Description: Possible example of the copper-alloy 'paper-clip' part of a 'paper-clip' repair References: Fasham et al. 1989, 81, Fig. 85(4).

Fison Way, Suffolk, England

Description: Four sheets of copper-alloy folded together. One of the sheets is decorated by repousse bosses References: Gregory 1991, 132, Fig. 117(26).

Gravelly Guy, Oxfordshire, England

Description: Folded and riveted copper-alloy sheet

References: Lambrick \& Allen 2004, Fig. 8.5(4).

Maiden Castle, Dorset, England

Description: Seven possible iron ring cauldron handles approximately $100 \mathrm{~mm}$ in diameter. Six are listed by Wheeler (1943) a seventh is illustrated in Sharples (1991) and discussed by Palk (in Sharples 1991, 165). Previously believed to be horse harnesses, Northover (in Sharples 1991, 161) states that they could be cauldron handles. In addition to the iron handles, a 
large quantity of sheet copper-alloy with attached rivets was also discovered at the site (Northover in Sharples 1991, 160). Some of the rivets and studs attached to these sheet fragments are identical to those used on cauldrons like the example from Spetisbury implying that at least some of these sheet fragments derive from cauldrons.

Dating: The context of the iron ring published in Sharples (1991) dates the handle to the early - mid first century BC.

References: Wheeler 1943, 275; Sharples 1991, 160-161, 165, Fig. 197(9).

\section{Mount Batten, Plymouth, England}

Description: A number of copper-alloy vessel fragments, including a substantial piece (No.13) which has been folded over. This could be large enough to be from a cauldron.

Dating: It dates to 'period 3e' which probably lies somewhere between 450/400-100 BC but could have been slightly later (Cunliffe 1988, 24). These finds are distinct from those examined in the same report by Northover (in Cunliffe 1988, 58-60) which belong to Atlantic Class B2 cauldrons.

References: Cunliffe 1988, 24-27, Fig. 15.

\section{APPENDIX E: RING HANDLES}

\section{Aylesford, Kent, England}

Location: British Museum, London (P\&E 1818.1824.26 \& 1818.1824.27)

Dimensions: External diameter of handles: $110 \mathrm{~mm}$

Type: Ring handles

Description: Two heavily corroded iron ring handles together with their iron attachments. Owing to the corrosion, it is difficult to be certain whether the attachments have two or three ribs. The handles are round in cross-section.

Discovery: From the well-known cremation cemetery. Unfortunately they were recovered prior to the excavation of the site so exact details are unclear.

References: Evans 1890, 319-20, Fig. 2.

Lesser Garth, Cardiff, Wales

Location: National Museum, Cardiff (65.82.3)

Dimensions: External diameter of handle: $88 \mathrm{~mm}$

Type: Ring Handle

Description: Iron ring handle complete with iron attachment comprising three ribs. The ring handle is circular in crosssection. The three ribs are fused together and form a D-shaped loop in cross-section, the ends of which are not joined. 
Unfortunately the handle attachment is broken off at the point where it affixed to the cauldron so it is now impossible to establish how this join was made. It is clear that the ring handle was free-moving within the attachment.

Discovery: Discovered in 1965 in the topsoil of a quarry. It was probably part of a hoard of iron which also contained a section of cauldron chain, cauldron hanger, knives, latch-lifter (all iron), and trade-iron billets. Items of chariot and horse fittings were also present: a bridle-bit and lynch pin (both iron), and a large, enamel decorated bronze chariot terret (flatringed central terret with three decorative bosses).

References: Savory 1966, 38, Fig. 3; Savory 1976, No. 35, Fig. 37.

Meare Lake Village, Somerset, England

Location: Taunton Archaeological Museum, Somerset

Dimensions: External diameter of handle: $118-121 \mathrm{~mm}$

Type: Ring Handle

Description: Iron ring handle with iron attachment comprising three ribs.

Discovery: From the west village at Meare

References: Bulleid \& Gray 1953, 243, PI. L.

Stanfordbury, Bedfordshire, England

Location: Museum of Archaeology and Anthropology, Cambridge (MAA 1988 05-23)

Type: Ring Handle

Description: Iron ring handle

Discovery: Stead \& Rigby state: "The only cauldron from a La Tène III burial in England came from the very centre of one of the Stanfordbury graves; but like the Baldock cauldron it disintegrated and only the handle survive. An iron tripod and a pair of fire-dogs were found in the same grave" (Stead \& Rigby 1986, 59).

References: Dryden 1845, 15-21; Fox 1923, 100, PI. XVII; Stead \& Rigby 1986, 59.

\section{BIBLIOGRAPHY}

Anderson, J. 1884-5. Notice of a bronze cauldron found with several small kegs of butter in a moss near Kyleakin in Skye: with notes of other cauldrons of bronze found in Scotland. Proceedings of the Society of Antiquaries of Scotland 19, 309-315. 
Anderson, R.S.G. 1938. A bronze bowl from the Rhinns of Galloway. Proceedings of the Society of Antiquaries of Scotland 72, 137-142.

Anon. 1866-8. Donations to the Library and Museum. Proceedings of the Society of Antiquaries of Scotland 7, 7-10.

Anon. 1889-90. Purchases for the Museum. Proceedings of the Society of Antiquaries of Scotland 24, 6-17.

Anon. 1924. Catalogue of well-known collection of prehistoric antiquities, etc. chiefly from Ireland formed by W.J. Knowles. London: Sotheby, Wilkinson and Hodge.

Armada, X.-L. 2008. ¿Carne, drogas o alcohol? Calderos y banquetes en el Bronce Final de la Península Ibérica. Cuadernos de Prehistoria y Arquelogía de la Universidad de Granada 18, 125-62.

Armada, X.-L. 2011. Feasting metals and the ideology of power in the Late Bronze Age of Atlantic Iberia. In G.A. Jiménez, S. Montón-Subias and M.S. Romero (eds), Guess who's coming to dinner: feasting rituals in the prehistoric societies of Europe and the Near East, 158-183. Oxford: Oxbow Books.

Armstrong, E.C.R. 1923. The La Tène period in Ireland. Journal of the Royal Society of Antiquaries of Ireland 53, $1-33$.

Arnold, B. 1999. 'Drinking the Feast': Alcohol and the Legitimation of Power in Celtic Europe. Cambridge Archaeological Journal 9(1), 71-93.

Barrett, J. C., Freeman, P. W. M. \& Woodward, A. 2000. Cadbury Castle, Somerset: the later prehistoric and early historic archaeology. London: English Heritage Archaeological Report 20.

Bataille, G. 2008. Les Celtes: des mobiliers aux cultes. Dijon: Èditions Univeritaires de Dijon. 
Barrett, J.C., Freeman, P. W. M. \& Woodward, A. 2000. Cadbury Castle, Somerset: the later prehistoric and early historic archaeology. London: English Heritage Archaeological Report 20.

Biel, J. 1987. Hochdorf. In J.-P. Mohen (ed.), Tresors de Princes Celtes, 95-188. Paris: Editions de la Réunion des musées nationaux.

Bochnak, T. 2011. Kierunki napływu celtyckich kotłów z żelaznym brzegiem jako odbicie oddziaływań latenizacyjnych w kulturze oksywskiej. Między Kulturq Pomorskq a Kulturq Oksywskq-Przemiany Kulturowe w Okresie, Muzeum Archeologiczne w Gdańsku, 57-77.

Boon, G.C. 1961. Roman Antiquities at Welshpool. Antiquaries Journal 41, 13-31.

Bowman, S. and Needham, S. 2007. The Dunaverney and Little Thetford flesh-hooks: history, technology and their position within the later Bronze Age Atlantic zone feasting complex. The Antiquaries Journal 87, 53-108.

Briggs, C.S. 1987. Buckets and cauldrons in the late Bronze Age of northwest Europe: a review. In J.C. Blanchet (ed.), Les relations entre le Continent et les lles Britanniques à l'Âge du Bronze. Actes du colloque de Bronze de Lille dans le cadre du 22ème Congrés préhistorique de France, 2-7 septembre 1984, 161-187. Amiens: Supplément a la Revue archéologique de Picardie.

Bulleid, A. and Gray, H.St. George. 1953. Meare Lake Village, a full description of the excavations and the relics from the eastern half of the west village, 1910-1933, Vol. II. Taunton: Taunton Castle.

Burns, J.E. 1969. A Bronze Cauldron of the Iron Age from Elvanfoot, Lanarkshire. Glasgow Archaeological Journal 1, 29-34.

Bray, T. L. 2003. (ed.). The Archaeology and Politics of Food and Feasting in Early States and Empires. New York: Kluwer Academic/Plenum. 
Bronk Ramsey, C. and Lee, S. 2013. Recent and Planned Developments of the Program OxCal. Radiocarbon 55(2-3), 720-730.

Clarke, R.R. 1939. The Iron Age in Norfolk and Suffolk. Archaeology Journal 96, 1-113.

Cunliffe, B. 1988. Mount Batten, Plymouth: a prehistoric and Roman port. Oxford: Oxford Committee for Archaeology Monograph 26.

Cunliffe, B. 2005. Iron Age communities in Britain: an account of England, Scotland and Wales from the seventh century BC until the Roman conquest ( $4^{\text {th }}$ edition). London: Routledge.

Cunliffe, B. and Poole, C. 1991. Danebury: an Iron Age hillfort in Hampshire. Volume 5: the excavations 19791988, the finds. London: Council for British Archaeology Report 73b.

Cunnington, M. E. 1920. Notes on objects from an inhabited site on the Worm's Head, Glamorgan. Archaeologia Cambrensis 20 (series 6), 251-256.

Curle, J. 1931-2. An inventory of objects of Roman and provincial Roman origin found on sites in Scotland not definitely associated with Roman constructions. Proceedings of Society of Antiquaries of Scotland 66, 277-397.

Déchelette, J. 1914. Manuel d'archéologie Celtique ou protohistorique: Troisième partie second age du fer ou époque de La Tène. Paris: Auguste Picard.

DES. 1992. Discovery and Excavation in Scotland. Edinburgh: Council for Scottish Archaeology.

Dietler, M. 1996. Feasts and Commensal Politics in the Political Economy: Food, Power and Status in Prehistoric Europe. In P. Wiessner and W. Schiefenhövel (eds), Food and the Status Quest: an Interdisciplinary Perspective, 87-125. Oxford: Berghahn Books. 
Dietler, M. 2001. Theorizing the Feast: Rituals of Consumption, Commensal Politics, and Power in African contexts. In M. Dietler and B. Hayden (eds), Feasts: Archaeological and Ethnographic Perspectives on Food, Politics and Power, 65-114. Tuscaloosa: The University of Alabama Press.

Dietler, M. and Hayden, B. 2001. (eds). Feasts: archaeological and ethnographic perspectives on food, politics and power. Tuscaloosa: The University of Alabama Press.

Dryden, H. 1845. Roman and Roman British remains, at and near Shefford, Co. Beds. Cambridge: Cambridge Antiquaries Society Publications.

Earwood, C. 1991. Two early historic bog butter containers. Proceedings of the Society of Antiquaries Scotland $121,231-240$.

Earwood, C. 1993. Domestic wooden artefacts in Britain and Ireland from Neolithic to Viking times. Exeter: University of Exeter Press.

Eggers, H.J. 1951. Der Römische import im Freien Germanien. Hamburg: Hamburg Museum Für Völkerkunde und Vorgeschichte.

Evans, A.J. 1890. On a late Celtic urnfield at Aylesford, Kent. Archaeologia 52, 325-88.

Fasham, P.J., Farwell, D.E. and Whinney, R. J. B. 1989. The archaeological site at Easton Lane, Winchester. Winchester: Hampshire Field Club Monograph 6.

Feacham, R.W. 1965. The North Britons: the prehistory of a border people. London: Hutchinson. 
Fitzpatrick. A. 2009. The Champion's Portion: feasting in the Celtic pre-Roman Iron Age. In G. Cooney, K. Becker, J. Coles, M. Ryan and S. Sievers (eds), Relics of Old Decency: archaeological studies in later prehistory, 389-404. Dublin: Wordwell.

Forsyth, J.F. 1964. Some notes on the bronze cauldron recovered from Loch Gamhna, Inverness-shire. Proceedings of the Society of Antiquaries of Scotland 97, 249-251.

Fox, C. 1923. The archaeology of the Cambridge region. Cambridge: Cambridge University Press.

Fox, C. 1946. A find of the early Iron Age from Llyn Cerrig Bach, Anglesey. Cardiff: National Museum of Wales.

Garrow, D., Gosden, C., Hill, J.D., and Bronk Ramsey, C. 2009. Dating Celtic Art: a Major Radiocarbon Dating Programme of Iron Age and Early Roman Metalwork in Britain. Archaeology Journal 166, 79-123.

Gerloff, S. 1986. Bronze Age Class A cauldrons: typology, origins and chronology. Journal of the Royal Society of Antiquaries Ireland 116, 84-115.

Gerloff, S. 2010. Atlantic cauldrons and buckets of the Late Bronze and Early Iron Ages in Western Europe: with a review of comparable vessels from Central Europe and Italy. Mainz: Prähistorische Bronzefunde Abteilung II, Band 18.

Ginoux, N.-C. 2009. Elites guerrières au nord de la Seine au début du Ille siècle av. J.-C. La nécropole celtique du Plessis-Gassot (Val-d’Oise). Lille: Revue du Nord. Hors série. Collection Art et Archéologie N 15, Université Charles-de-Gaulle - Lille 3.

Goody, J. 1982. Cooking, Cuisine and Class: A study in Comparative Sociology. Cambridge: Cambridge University Press. 
Gosden, C. and Garrow, D. 2012. Technologies of Enchantment? Exploring Celtic art: 400 BC to AD 100. Oxford: Oxford University Press.

Green, M.J. 1998. Vessels of death: sacred cauldrons in archaeology and myth. Antiquaries Journal 78, 63-84.

Gregory, T. 1978. A bronze bowl from Upwell. Norfolk Archaeology 37(1): 134.

Gregory, T. 1991. Excavations in Thetford 1980-1982, Fison Way. Volume 1. Dereham: East Anglian Archaeology Report 53.

Gresham, C.A. 1939. Spetisbury Rings, Dorset. Archaeological Journal 96, 114-31.

Griffiths, W.E. 1948. Topographical list of Roman remains found in north Wales. Bulletin Board of Celtic Studies XII, 120.

Guilbert, G. 1979. Dinorben 1977-8. Current Archaeology 65, 182-188.

Gwilt, A. 2007. Silent Silures? Locating people and places in the Iron Age of South Wales. In C. Haselgrove and T. Moore (eds), The Later Iron Age in Britain and beyond, 297-328. Oxford: Oxbow Books.

Gwilt, A. (forthcoming 2014). The dating of the Welshpool Grave Assemblage: radiocarbon dating evidence and review. Montgomeryshire Collections 102.

Hatley, A.R. 1933. Early days in the Walthamstow District. Walthamstow: Walthamstow Antiquarian Society Official Publication 28. 
Hawkes, C.F.C. 1951. Bronze-workers, cauldrons and bucket-animals in Iron Age and Roman Britain. In W. F. Grimes (ed.), Aspects of Archaeology in Britain and Beyond essays presented to O.G.S. Crawford, 172-199. London: H. W. Edwards.

Hawkes, C.F.C. and Smith, M.A. 1957. On some buckets and cauldrons of the bronze and early Iron Ages. Antiquaries Journal 37, 131-198.

Hayden, B. 2001. Fabulous Feasts: A Prolegomenon to the Importance of Feasting. In M. Dietler and B. Hayden (eds), Feasts: Archaeological and Ethnographic Perspectives on Food, Politics and Power, 23-64. Tuscaloosa: The University of Alabama Press.

Hunter, F. 1997. Iron Age hoarding in Scotland and northern England. In A. Gwilt and C. Haselgrove (eds), Reconstructing Iron Age Societies, 108-34. Oxford: Oxbow Monograph 71.

Jackson, R. 1990. Camerton: the late Iron Age and early Roman metalwork. London: British Museum Press.

Jacobi, J. 1974. Die Ausgrabungen in Manching 5: Werkzeuge und Gerät aus dem Oppidum von Manching. Stuttgart: Franz Steiner Verlag.

Jacobsthal, P. 1969 [1944]. Early Celtic Art (2 ${ }^{\text {nd }}$ ed.). Oxford: Clarendon Press.

Joy, J. 2008. Reflections on Celtic Art: a re-examination of mirror decoration. In D. Garrow, C. Gosden and J.D. Hill (eds), Rethinking Celtic Art, 78-99. Oxford: Oxbow Books.

Joy, J. 2011. 'Fancy Objects' in the British Iron Age: Why Decorate? Proceedings of the Prehistoric Society 77, 205-229.

Joy, J. and Baldwin, A. forthcoming. The Bubbling Cauldron: The Iron Age Cauldrons from Chiseldon, Wiltshire. London: British Museum Press. 
Klindt-Jensen, O. 1953. Bronzekedelen fra Brå. Aarhus: Aarhus University Press.

Lambrick, G. and Allen, T. 2004. Gravelly Guy, Stanton Harcourt: the development of a prehistoric and RomanoBritish community. Oxford: Oxford Archaeology Thames Valley Landscapes Monograph 21.

Leeds, E. T. 1930. A bronze cauldron from the River Cherwell, Oxfordshire, with notes on cauldrons and other bronze vessels of allied types. Archaeologia 80: 1-36.

Lévi-Strauss, C. 1968. L'Origine des Manieres de Table. Paris: Plon.

Loughran, A. 1989. Iron Age Cauldrons in Northwest Europe. Unpublished MA Thesis, National University of Ireland, Dublin.

Macdonald, P. 2007. Llyn Cerrig Bach: a study of the copper alloy artefacts from the insular La Tène assemblage. Cardiff: University of Wales Press.

Macgregor, M. 1976. Early Celtic Art in North Britain: a study of decorative metalwork from the third century B.C. to the third century A.D. Leicester: Leicester University Press.

Maguer, P., Cherel, A. F. and Auxiette, G. 2003. Nouvelles données sur les habitats de l'Age du Fer dans le nord de la Sarthe (commune de Vivoin, autoroute A28). In B. Mandy and A. de Saulce (eds), Les marges de I'Armorique à l'âge du Fer: archéologie et histoire: culture materielle et sources écrites. XXIII colloque de l', Nantes, 13-16 mai 1999, 213-234. Rennes: Revue Archéologique de l'Ouest 10.

Manning, W. H. 1972. Ironwork Hoards in Iron Age and Roman Britain. Britannia 3, 224-250.

Manning, W.H. 1983. The cauldron chains of Iron Age and Roman Britain. In B. Hartley and J. Wacher (eds), Rome and her northern provinces, 132-154. Gloucester: Alan Sutton Publishing. 
Maryon, H. 1938. The technical methods of the Irish smiths in the Bronze and early Iron Ages. Proceedings of the Royal Irish Academy 44, 181-228.

Maryon, H. 1949. Metalworking in the ancient world. American Journal of Archaeology 53, 93-125.

Mattison, W.K. and Palmer, L.S. 1937. Note on a Bronze Cauldron from Craven in Yorkshire. Proceedings of the Prehistoric Society 3, 164-165.

McEvoy, E. 1854-5. Urlingford: a magnificent specimen of the antique bronze cauldrons which seem to be peculiar to Ireland: and a St. Patrick's half-penny. Journal of the Royal Society of Antiquaries of Ireland 3, 131-2.

Mortensen, P. 1991. The Brå Cauldron. In S. Moscati, O. H. Frey, B. Raftery, and M. Szabó (eds), The Celts, 375. New York: Rizzoli.

Moss-Eccardt, J. 1965. An iron cauldron-rim from Letchworth, Herts. Antiquaries Journal 95, 173-177.

Moss-Eccardt, J. 1988. Archaeological investigations in the Letchworth area, 1958-1974: Blackhorse Road, Letchworth; Norton Road, Baldock; Wilbury Hill, Letchworth. Proceedings of the Cambridge Antiquaries Society 77, 35-103.

Needham, S. and Bowman, S. 2005. Flesh-hooks, technological complexity and the Atlantic Bronze Age feasting complex. European Journal of Archaeology 8(2), 93-136.

Newton, W.W.H. 1852. Discovery of bronze vessels. \&c, at Cockburnspath, Berwickshire. Proceedings of Society of Antiquaries of Scotland 1, 43-4.

Piggott, S. 1952-3. Three metal-work hoards of the Roman period from Southern Scotland. Proceedings of Society of Antiquaries of Scotland 87, 1-50. 
Piggott, S. 1970. Early Celtic art. Edinburgh: Edinburgh University Press.

Poux, M. 2004. L'Âge du Vin: Rites de boisson, festins et libations en Gaule indépendante. Montagnac: Éditions Monique Mergoil. Protohistoire Européenne 8.

Prüssing, G. 1991. Die bronzefäße in Österreich. Stuttgart: Prähistorische Bronzefunde Abteilung II, Band 5.

Raftery, B. 1980. Iron Age cauldrons in Ireland. Archaeologia Atlantica 3, 57-80.

Raftery, B. 1983. A catalogue of Irish Iron Age antiquities. Marburg: Veröffentlinchung Des Vergeschichtlichen Seminars - Sonderband 1.

Raftery, B. 1984. La Tène in Ireland: problems of origin and chronology. Marburg: Veröffentlinchung Des Vergeschichtlichen Seminars - Sonderband 2.

Raftery, J. 1963. National Museum of Ireland archaeological acquisitions for the year 1961. Journal of the Royal Society of Antiquaries of Ireland 93, 115-33.

Ralph, S. 2007. Feasting and Social Complexity in later Iron Age East Anglia (Oxford: BAR British Series 451).

Redknap, M. (ed.). 2011. Discovered in Time: Treasures from Early Wales. Cardiff: National Museum of Wales Books.

Reimer, P. J., Bard, E., Bayliss, A., Beck, J. W., Blackwell, P. G., Bronk Ramsey, C., Grootes, P. M., Guilderson, T. P., Haflidason, H., Hajdas, I., HattŽ, C., Heaton, T. J., Hoffmann, D. L., Hogg, A. G., Hughen, K. A., Kaiser, K. F., Kromer, B., Manning, S. W., Niu, M., Reimer, R. W., Richards, D. A., Scott, E. M., Southon, J. R., Staff, R. A., Turney, C. S. M., and van der Plicht, J. 2013. IntCal13 and Marine13 Radiocarbon Age Calibration Curves 050,000 Years cal. BP. Radiocarbon 55(4), 1869-1887. 
Ross, A. 1967. Pagan Celtic Britain: studies in iconography and tradition. London: Routledge \& Kegan Paul.

Rynne, E. 1960. A bronze cauldron from Ballyedmond, Co. Galway. Journal of the Galway Archaeological and Historical Society 29(1-2), 1-2.

Savory, H.N. 1966. A find from early Iron Age metalwork from the Lesser Garth, Pentyrch (Glam.). Archaeologia Cambrensis 115, 27-44.

Savory, H.N. 1976. Guide catalogue of the early Iron Age collections. Cardiff: National Museum of Wales.

Sealey, P. R. 1999. Finds from the cauldron pit. In O. Bedwin (ed.), The Archaeology of Ardleigh, Essex.

Excavations 1955-1980, 117-124. Chelmsford: East Anglian Archaeology Report.

Sealey, P. R. 2007. A Late Iron Age Warrior Burial from Kelvedon, Essex. Colchester: East Anglian Archaeology Report No. 118.

Sealey, P. R. 2009. New Light on the Wine Trade in Julio-Claudian Britain. Britannia 40, 1-40.

Sharples, N.M. 1991. Maiden Castle: excavations and field survey 1985-6. London: English Heritage Archaeological Report 19.

Smith, R.A. 1906-7. The timekeepers of the ancient Britons. Proceedings of the Society of Antiquaries, London $\left(2^{\text {nd }}\right.$ series) $21,319-33$.

Smith, R.A. 1909. A Hoard of Metal found at Santon Downham, Suffolk. Proceedings of Cambridge Antiquarian Society $13,146-63$. 
Smith, R.A. 1914-15. A series of thin bronze vessels including water-clocks of the Early Iron Age, discovered at Wotton, Surrey. Proceedings of the Society of Antiquaries, London ( $2^{\text {nd }}$ series) $27,76-95$.

Smith, R.A. 1925. Guide to Early Iron Age Antiquities ( $2^{\text {nd }}$ edition). London: British Museum.

Spratling, M.G. 1971. Further Comments on the Iron Age Cauldron from Elvanfoot, Lanarkshire. Glasgow Archaeological Journal 2, 111-112.

Spratling, M.G. 1972. Southern British decorated bronzes of the late pre-Roman Iron Age. Unpublished Ph.D. thesis, University of London.

Spratling, M. G. 1975. Fragments of a lorica segmentata in the hoard from Santon, Norfolk. Britannia 6, 206$207 .$.

Spratling, M. G. 2009 [1966]. The Santon Hoard Reconsidered: a rich burial of the mid-first century AD from Norfolk. University of Cardiff: unpublished B.A. dissertation.

Stead, I.M. 1971. The reconstruction of Iron Age buckets from Aylesford and Baldock. British Museum Quarterly 35, 250-282.

Stead, I. M. 1996 [1985]. Celtic art in Britain before the Roman Conquest (2 ${ }^{\text {nd }}$ ed.). London: British Museum Press.

Stead, I.M. and Rigby, V. 1986. Baldock: the excavation of a Roman and pre-Roman settlement, 1968-72. London: Britannia Monograph Series 7.

Thomas, N. 2005. Conderton Camp, Worcestershire: A small middle Iron Age hillfort on Bredon Hill. London: Council for British Archaeology Research Report 143. 
Tylecote, R.F. 1962. Metallurgy in archaeology. A prehistory of metallurgy in the British Isles. London: Edward Arnold.

Verger, S. 1997. L'Incinération en urne métallique: un indicateur des contacts aristocratiques transalpins. In P. Brun and B. Chaume (eds), Vix et les éphémères principautés celtiques. Les VI et $V^{e}$ siècles avant J.-C. en Europe cerre-occidentale, 223-238. Paris: Editions Errance.

Vouga, P. 1923. La Tène: monographie de la station publiée au nom de la commission des fouilles de La Tène. Leipzig: Karl W. Hiersemann.

Watkin, J., Stead, I., Hook, D. and Palmer, S. 1996. A decorated shield-boss from the River Trent, near Ratcliffeon-Soar. Antiquaries Journal 76, 17-30.

Wiessner, P. and Schiefenhövel, W. (eds). 1996. Food and the status quest, interdisciplinary perspective. Providence: Berghahn.

Wheeler, R.E.M. 1943. Maiden Castle, Dorset. Oxford: Oxford University Press. 


\section{LIST OF FIGURES}

Figure 1: Schematic illustration of a cauldron with terminology (drawn by Stephen Crummy)

Figure 2: Globular and Projecting-bellied cauldrons (drawn by Stephen Crummy)

Figure 3: Cauldron Typology. The colour contrast does not equate to the use of iron vs. bronze but is rather aimed at highlighting the differences between the groups (drawn by Stephen Crummy)

Figure 4: Frequency of cauldrons by type (the key begins at 12 o'clock, working clockwise)

Figure 5: Different contexts IA/ER cauldrons are found in (the key begins at 12 o'clock, working clockwise)

Figure 6: Context by cauldron group (the keys begin at 12 o'clock, working clockwise)

Figure 7: Height and maximum diameter of cauldrons plotted by type

Figure 8: Volume of cauldrons defined by group

Figure 9: Distribution of cauldrons by type (drawn by Craig Williams)

Figure 10: Diagram of cauldron SF7 from Chiseldon, Wiltshire illustrating its complexity (drawn by Stephen Crummy, (C) Trustees of the British Museum)

Figure 11: Decorated cow's head mount on cauldron SF7 from Chiseldon, Wiltshire (drawn by Craig Williams, (C) Trustees of the British Museum)

Figure 12: Waldalgesheim or Vegetal style decoration on cauldron SF10 from Chiseldon, Wiltshire (drawn by Craig Williams, (C) Trustees of the British Museum) 
'The author is extremely grateful to Professor Eamonn Kelly and Eamonn McLoughlin of the National Museum of Ireland for providing this information and allowing it to be re-produced here.

ii Perhaps because of the size and unwieldiness of cauldrons, published measurements vary widely. For consistency, where the author has not measured the object, all measurements are taken from Loughran (1989). This is because hers is the most extensive catalogue. Catalogue entries where the object has not been seen by the author and are reliant on published information are marked with an *.

iii Where the author has not seen the cauldron, notes of repairs are taken from the literature. Where there is disagreement, Loughran's numbers are used, again for consistency. 